OPEN ACCESS

Edited by:

Philipp Henneke,

University of Freiburg, Germany

Reviewed by:

Tara Marlene Strutt,

University of Central Florida,

United States

Craig Michael Walsh,

University of California, Irvine,

United States

${ }^{*}$ Correspondence:

Bahaa Abu-Raya

baburaya@bcchr.ubc.ca

${ }^{\dagger}$ These authors have contributed

equally to this work

Specialty section:

This article was submitted to Immunological Memory,

a section of the journal

Frontiers in Immunology

Received: 22 June 2020

Accepted: 18 September 2020

Published: 07 October 2020

Citation:

Abu-Raya B, Michalski C, Sadarangani M and Lavoie PM (2020) Maternal Immunological Adaptation

During Normal Pregnancy.

Front. Immunol. 11:575197. doi: 10.3389/fimmu.2020.575197

\section{Maternal Immunological Adaptation During Normal Pregnancy}

\author{
Bahaa Abu-Raya ${ }^{1,2,3,4 * t}$, Christina Michalski ${ }^{2,3,4 \dagger}$, Manish Sadarangani ${ }^{1,2,3,4}$ \\ and Pascal M. Lavoie ${ }^{2,3,4}$ \\ 1 Vaccine Evaluation Center, BC Children's Hospital Research Institute, Vancouver, BC, Canada, ${ }^{2}$ BC Children's Hospital \\ Research Institute, Vancouver, BC, Canada, ${ }^{3}$ Department of Pediatrics, University of British Columbia, Vancouver, BC, Canada, \\ ${ }^{4}$ Experimental Medicine Program, Faculty of Medicine, University of British Columbia, Vancouver, BC, Canada
}

The risk and severity of specific infections are increased during pregnancy due to a combination of physiological and immunological changes. Characterizing the maternal immune system during pregnancy is important to understand how the maternal immune system maintains tolerance towards the allogeneic fetus. This may also inform strategies to prevent maternal fatalities due to infections and optimize maternal vaccination to best protect the mother-fetus dyad and the infant after birth. In this review, we describe what is known about the immunological changes that occur during a normal pregnancy.

Keywords: immune system, humoral immune response, cellular immune response, gestation, immunity, fetal

\section{INTRODUCTION}

During pregnancy, major adaptations occur in the maternal immune system to protect the mother and her future baby from pathogens while avoiding detrimental immune responses against the allogeneic fetus. While there is little evidence to support that the maternal immune system is globally suppressed during pregnancy, increased risks for certain types of infections indicate important qualitative immunological changes (1). Due to the complexity and unique circumstances surrounding a normal pregnancy, teasing out how specific endocrinological, physiological and immunological factors increase the risk of infection requires careful considerations. For example, urinary tract infections may be more common or pneumonia may be more severe during pregnancy largely because of circulatory changes and reduced functional residual lung capacity due to increased abdominal pressure $(2,3)$. Other types of infections may be simply more frequently reported because of their severe clinical consequences on the fetus (Table 1). A better understanding of immunological changes during pregnancy may also be important in considering optimal strategies for use of vaccines, such as influenza and pertussis, to protect both the pregnant woman and infant (73). Nonetheless, these examples reveal the complexity of understanding how physiological, hormonal and immunological adaptation during normal pregnancy directly impacts the risk of infection. Major adaptations at the maternal-fetal interface have been discussed in recent reviews $(74,75)$. Local immunological adaptation in the placenta has been reviewed (76). In this review article, we describe the dynamic changes occurring in the peripheral maternal immune system during normal pregnancy. 
TABLE 1 | Infections associated with increased maternal susceptibility or severity during pregnancy, or severe adverse fetal outcomes.

\begin{tabular}{|c|c|}
\hline Infection & Reference \\
\hline \multicolumn{2}{|l|}{ Increased maternal susceptibility } \\
\hline Listerisosis & $4-10$ \\
\hline Tuberculosis (during the puerperium) & 11,12 \\
\hline Malaria & $13-16$ \\
\hline \multicolumn{2}{|l|}{ Increased maternal severity } \\
\hline Influenza & $17-22$ \\
\hline Varicella Zoster Virus infection & $23-27$ \\
\hline Hepatitis E virus infection & $28-31$ \\
\hline Malaria & $14,32-35$ \\
\hline Invasive Haemophilus influenza infection & 36-38 \\
\hline Invasive pneumococcal disease & 39 \\
\hline Invasive group A streptococcal disease & 39 \\
\hline Dengue fever & 40 \\
\hline Lassa Fever & 41,42 \\
\hline Ebola virus & 41 \\
\hline Primary Herpes Simplex Virus infection & $43-45$ \\
\hline Coccidiomycosis $^{\dagger}$ & $46-50$ \\
\hline Measles & 51,52 \\
\hline \multicolumn{2}{|l|}{ Severe adverse fetal outcomes } \\
\hline Toxoplasmosis & 53,54 \\
\hline Influenza & $17,19,21,55-58$ \\
\hline Primary varicella zoster virus infection & 24,59 \\
\hline Malaria & 33 \\
\hline Rubella & $60-62$ \\
\hline Parvovirus B19 & 63 \\
\hline Listeriosis & $4,9,64,65$ \\
\hline Tuberculosis & 66,67 \\
\hline Zika virus & 68,69 \\
\hline Measles & $52,61,70,71$ \\
\hline Mumps & 70 \\
\hline Cytomegalovirus & 72 \\
\hline
\end{tabular}

${ }^{+}$some data suggest increased maternal severity while other data do not suggest this association.

\section{INNATE IMMUNITY}

\section{Complement System}

Studies suggest increased complement activity during pregnancy (Table 2). Plasma levels of C3a, C4a, C5a, C4d, C3a, C3, C9, and the Serum Complement Membrane Attack Complex SC5b9 are elevated during pregnancy $(77,78,106)$. Altogether, this increase in cleaved complement proteins suggests upregulation of complement activity in pregnant women while the balance is maintained through high levels of regulatory proteins such as factor $\mathrm{H}$ which blocks the alternative C3 convertase (79). Consistent with this, the complement inhibitor Decayaccelerating factor (DAF), also known as CD55, is increased in peripheral blood mononuclear cells during pregnancy (80). By blocking formation of C3 convertases, DAF effectively inhibits downstream effects of complement activation. Similarly, the C3 inhibitor pregnancy-associated plasma protein A (PAPPA) increases during the second and third trimesters $(81,82)$. Complement hemolytic activity ( $\mathrm{CH} 50)$ reflects activity of the classical complement pathway. Serum CH50 increase as pregnancy progresses $(83,84)$. Increased complement activity has been linked to pre-eclampsia and preterm birth (107), suggesting that balancing complement activation is necessary for a healthy pregnancy [reviewed in (108)].
Pregnancy is a hypercoagulable state, with a four-fold increased risk for deep vein thrombosis when compared to non-pregnant women (109). There is an interaction between acute phase proteins, the coagulation and the complement systems. C-reactive protein (CRP) activates C1, C4, C2, and C3 (110-112) and serum CRP levels are elevated during pregnancy (85). Fibrinogen and factor VII are part of the coagulation cascade that independently activates the complement system, for example, thrombin has been shown to cleave C3 and C5 [reviewed in (113)]. Fibrinogen and factor VII are also increased during pregnancy (86), further supporting the notion that the complement system is activated in pregnancy. High levels of procoagulant factors are counter-balanced by increased plasma levels of pregnancy-specific glycoproteins (PSGs). These placenta-derived molecules prevent platelet activation in an integrin-dependent manner (114).

\section{Granulocytes}

Eosinophil and basophil counts are not affected by pregnancy (Table 2) (85, 86). However, urinary eosinophil-derived neurotoxin secretion is elevated during the second and third trimester, suggesting increased eosinophil degranulation. In contrast, urinary $\mathrm{N}$-methylhistamine concentrations are lower in the third trimester, suggesting reduced mast cell degranulation (87).

Neutrophils kill micro-organisms through phagocytosis, Neutrophil Extracellular Traps (NETs), production of toxic granules and reactive oxygen species (ROSs) (115). There is a gradual, marked increase in neutrophils from the first trimester onwards $(85,88)$. Consistent with this, G-CSF and GM-CSF, two cytokines mediating bone marrow neutrophil production, are also elevated during pregnancy $(85,116)$. The function of neutrophils may also be altered during pregnancy. Neutrophils are highenergy need cells that depend on glycolysis for ATP production, and reserve oxygen towards production of ROSs and nitrogen species by the mitochondria. To meet their metabolic demands, glucose is metabolized through the hexose monophosphate shunt, which produces NADPH for the oxidative burst. Activation of neutrophils leads to translocation of metabolic enzymes to the cell membrane where they form enzyme complexes, increasing efficiency of these anabolic processes. Neutrophils from pregnant women exhibit retrograde transport of these metabolic enzymes to centrosomes, suggesting active prevention of metabolic upregulation $(89,90)$ : Glucose-6-phosphate dehydrogenase and 6-phosphogluconate dehydrogenase remain functional in neutrophils during pregnancy, but since their activity is restricted to the cytoplasm, the metabolic output is dampened $(89,90)$. This may explain why in vitro activated neutrophils from pregnant women show reduced respiratory burst activity and are refractory to priming with IFN- $\gamma$ (89-91). In contrast, unstimulated neutrophils from pregnant women have increased oxidative burst and produce ROS levels that are comparable to stimulated neutrophils from non-pregnant women $(90,92)$. In addition to ROS production, neutrophils also augment NETosis during pregnancy, with a continuous increase throughout gestation (117). Overall, these in vitro studies indicate that basal neutrophil function is increased at 
TABLE 2 | Changes in complement, granulocytes and monocytes during normal pregnancy.

Component Main findings

References

Complement

Levels Elevated $\mathrm{C} 3 \mathrm{a}, \mathrm{C} 4 \mathrm{a}$, and $\mathrm{C} 5 \mathrm{a}$ in the second and third trimester in comparison to non-pregnant women Elevated C4d, C3a, C3, C9, the Serum Complement Membrane Attack Complex SC5b9 during pregnancy.

Regulatory High levels of regulatory proteins (e.g. Factor H).

proteins

Increased levels of the complement inhibitor Decay-accelerating factor (CD55) on peripheral blood mononuclear cells during pregnancy. Increased levels of the C3 inhibitor pregnancy-associated plasma protein A during the second and third trimesters.

CH50 No change in serum $\mathrm{CH} 50$ titers during the first trimester but significantly increased in the second and third trimester as compared to non-pregnant women

Increase in $\mathrm{CH} 50$ levels in healthy pregnancy as compared to non-pregnant women and as pregnancy progressed, $\mathrm{CH} 50$ levels increased.

Granulocytes

Eosinophil and basophil counts were not affected by pregnancy.

Increased eosinophil degranulation during the second and third trimester and reduced mast cell degranulation during the last trimester, compared to non-pregnant women.

Increase in neutrophil counts from the first trimester onwards.

Neutrophils from pregnant women exhibit retrograde transport of metabolic enzymes to centrosomes, suggesting active prevention of metabolic upregulation

In vitro activated neutrophils from pregnant women show reduced respiratory burst activity and are refractory to priming with IFN- $\gamma$. Unstimulated neutrophils from pregnant women produce ROS at levels comparable to stimulated non-pregnancy neutrophils and have increased oxidative burst.

Elevated levels of elastase and lactoferrin in plasma from pregnant women, especially in the first trimester.

Unchanged or lower amounts of granule protein per granulocyte during pregnancy, and decreased as pregnancy progresses.

Reduced phagocytosis of neutrophils during pregnancy.

Increased expression of the activation marker Human Neutrophil Antigen-2a, during pregnancy and levels remained elevated for at least 4-8 weeks postpartum compared to non-pregnant women.

No difference in surface expression of the neutrophil activation markers CD11b, CD15, CD18, and CD62L between pregnant and nonpregnant women, neither in resting nor in stimulated neutrophils.

Elevated levels of CD11b expression on granulocytes in late pregnancy.

Increased levels of TLR4 co-receptor CD14 and the Fc receptor CD64 on granulocytes in the second and third trimesters compared to non-pregnant women.

Reduced expression of the neutrophil maturity marker CD16 and the MHC II molecule HLA-DR on granulocytes in pregnant women.

Decrease in CD10 levels and increase in CD15 levels on neutrophils over the course of pregnancy.

Monocytes

Granulocytic but not monocytic MDSCs are elevated in pregnant women.

Increases in monocyte numbers during pregnancy, mainly due to a higher number of "intermediate" monocytes, where classical monocytes decrease, with no change in the proportion of non-classical monocytes.

Elevated stimulation-induced IL-12 and TNF $\alpha$ production by monocytes from pregnant women throughout all three trimesters. Increased levels of activation markers CD11a, CD11b, CD14, and CD64, and higher ROS production by monocytes from pregnant women.

Monocytes in pregnant women are anti-inflammatory and show phenotypic signs of endotoxin tolerance.

Reduced LPS-induced IL-12 and TNF $\alpha$ production by monocytes of third trimester pregnant women as compared to non-pregnant controls.

Lower expression of several HLA coding genes on monocytes from first-trimester pregnant women compared to non-pregnant women Upregulation of genes coding for IL-10 and IDO and the negative immune regulator CD200, and a down-regulation of transcripts for IL8 and CXCL10 in monocytes from first trimester pregnancy.

Reduction in non-classical monocytes and an increase in classical monocytes in the third trimester compared to healthy controls.

77
78

79

80

81, 82

83

84

85, 86

87

85, 88

89,90

$89-91$

90, 92

85

85, 91

93

94

91, 92

95

92

96

97

98-101

102,103

88,92

99, 104

99

98

98

105

CH50, 50\% haemolytic complement; IFN- $\gamma$, Interferon- $\gamma$, ROS, Reactive oxygen species; TLR, Toll-like receptors; MHC, major histocompatibility complex; HLA-DR, Human Leukocyte Antigen-DR; MDSC, myeloid-derived suppressor cell; TNF $\alpha$, tumor necrosis factor $\alpha$; LPS, Lipopolysaccharides; IDO, Indoleamine 2,3-dioxygenase.

rest but decreased after activation during pregnancy. The distinction between resting and activated neutrophils may explain seemingly contradictory reports of the activity of neutrophils during pregnancy. The increased baseline neutrophil activity in pregnancy may be due to a more efficient plasma membrane cell surface localization of the cytoplasmic enzyme myeloperoxidase upon stimulation (118). Constitutive cell surface expression during pregnancy may lead to continuous production of ROSs without the need for re-stimulation.

Data support altered neutrophil phagocytosis during pregnancy (93). Elastase and lactoferrin are secreted from primary and secondary neutrophil granules, respectively, and are elevated in the first trimester (85). While elevated levels might indicate increased neutrophil activation, the amount of elastase or lactoferrin protein per granulocyte is unchanged or even lower as pregnancy progresses $(85,91)$. Thus, elevated plasma levels may simply reflect increased granulocyte numbers during pregnancy. Expression of the activation marker Human Neutrophil Antigen-2a (HNA-2a), also known as NB1 or CD177, increases during pregnancy and remains elevated for at least 4-8 weeks postpartum compared to nonpregnant women (94). On the other hand, surface expression of the neutrophil activation markers CD11b, CD15, CD18, and CD62L is not different between pregnant and non-pregnant 
women $(91,92)$. Neutrophils can present antigens to $\mathrm{T}$ lymphocytes through the MHC II molecule HLA-DR (119). Expression of the neutrophil maturity marker CD16 and HLADR were reduced on granulocytes in pregnant women in one study (92). Another study reported elevated CD11b expression on granulocytes in late pregnancy, but several of the women were in labor at the time of blood collection, which may have skewed the results (95). One study showed that TLR2 and TLR4 mRNA expression was comparable between pregnant and non-pregnant women (120). In contrast, expression of the TLR4 co-receptor CD14 and the Fc receptor CD64 were elevated on granulocytes in the second and third trimesters, supporting an increased neutrophil activation during pregnancy (92). Altogether, data suggest increased neutrophil activation during pregnancy but their potential to execute effector functions (e.g. antigen presentation), may be limited.

Decreased neutrophil expression of CD10 and increased expression of CD15 have been reported during the course of pregnancy (96). This phenotype $\left(\mathrm{CD} 10^{\text {low }}, \mathrm{CD} 15^{\text {high }}\right)$ was most pronounced during the third trimester and is characteristic of immature-like neutrophils (96). Many studies use density centrifugation to isolate neutrophils, which results in a loss of low-density immature-like neutrophils. The same lowdensity fraction also contains Myeloid-Derived Suppressor Cells (MDSCs), a heterogenetic group of mature, and immature-state monocytic or granulocytic cells that have immunosuppressive function. MDSCs are not normally detected in peripheral blood of healthy adults but common in cancer patients or newborns [reviewed in (121)]. The number of circulating granulocytic but not monocytic MDSCs is higher in pregnant women (97). Low MDSCs levels during pregnancy have been associated with miscarriage (122), thus, MDSCs might be important in maintaining adequate immunosuppression at the maternal-fetal interface.

\section{Monocytes}

Three main subsets of monocytes have been characterized in humans. Classical monocytes $\left(\mathrm{CD} 14^{\text {high }} \mathrm{CD} 16^{-}\right)$are the main subset in peripheral blood of healthy adults $(\sim 80 \%$ of all monocytes) and have phagocytic functions. Non-classical monocytes (CD14 ${ }^{\text {low }} \mathrm{CD} 16^{\text {high }}$ ) are inflammatory and high levels in peripheral blood have been observed in adults suffering from chronic or acute inflammatory diseases (123). Intermediate monocytes $\left(\mathrm{CD} 14^{\text {high }} \mathrm{CD} 16^{\text {intermediate }}\right)$ may represent a transitional state, displaying both inflammatory and phagocytic capacity (123). Monocytes also present antigens to $\mathrm{T}$ cells, hence modulating adaptive immune responses.

The impact of pregnancy on maternal monocyte function has been reviewed elsewhere $(124,125)$ and we will only briefly summarize key points here. Monocytes increase during pregnancy, beginning in the first trimester (Table 2) $(98,99)$. This increase is mainly due to higher levels of "intermediate" monocytes, whereas classical monocytes decrease, with no change in the proportion of non-classical monocytes (100, 101). An increase in intermediate monocytes could explain observations of elevated stimulation-induced IL-12 and TNF $\alpha$ production by monocytes from pregnant women throughout pregnancy $(102,103)$ and decreased phagocytosis during pregnancy (93). Increased pro-inflammatory activity of monocytes is further corroborated by increased levels of activation markers CD11a, CD11b, CD14, and CD64, and higher ROS production by monocytes from pregnant women $(88,92)$. The increased numbers of non-classical monocytes and elevated monocyte activation may be partially caused by placenta-secreted molecules and cellular particles [reviewed in (125)]. For example, placenta-derived extracellular vesicles have been shown to induce monocyte maturation and activation ex vivo (126). Additionally, hormonal changes in pregnancy may influence monocyte activity (127).

Contrasting with the findings above, monocytes in pregnant women are anti-inflammatory and show phenotypic signs of endotoxin tolerance as observed during the later phase of sepsis (99, 104). In peripheral blood of third trimester pregnant women, LPS-induced IL-12 and TNF $\alpha$ production by monocytes was reduced as compared to non-pregnant controls $(99,127)$. Additionally, several HLA coding genes are expressed at lower levels on monocytes from first-trimester pregnant women compared to non-pregnant women (98) and surface expression of MHC II is reduced (101). Together, this is reminiscent of an anti-inflammatory state observed in sepsis where an initial strong pro-inflammatory response is followed by immune paralysis (128). As in sepsis, the timing of the blood draw during gestation might influence the immunological changes reported. Several studies reported increased TNF $\alpha$ and IL-12 production by monocytes from pregnant women using IFN- $\boldsymbol{\gamma}$ in their stimulation cocktail $(102,103)$. IFN- $\boldsymbol{\gamma}$ has long been known to reverse the paralysis in septic monocytes (129), hence it is plausible that during pregnancy, maternal monocytes are in a chronically, low-grade inflammatory but unresponsive state which can be overcome with adequate stimulation (130).

This pro-inflammatory state is balanced by upregulation of regulatory features. Genes coding for IL-10 and IDO and the negative immune regulator CD200 are upregulated, while transcripts for IL8 and CXCL10 were downregulated on monocytes from first-trimester pregnancy (98). Consistent with this, a reduction in non-classical monocytes and an increase in classical monocytes in the third trimester of pregnancy compared to healthy controls has been reported (105).

While the described results seem contradictory, they may indicate that pregnancy induces specific immunological changes that evade oversimplified comparison to disease states. For example, similar to granulocytes, monocytes are confronted with an increased demand for phagocytosis during pregnancy due to presence of fetal and placental cells and particles in circulation. This could be achieved by an increase in classical monocytes. However, increased antigen uptake must be carefully balanced against a suppression of antigen-presenting functions to lymphocytes in order to prevent allogeneic rejection of the fetus, exemplified by reduced MHC II expression on monocytes from pregnant women (101). Moreover, conflicting data may be caused by differences in the study design (e.g. gestational age at sampling) and cell isolation method. For instance, PBMC 
isolation has been shown to affect the ratio of non-classical to classical monocytes detected (123).

\section{Innate Lymphoid Cells}

Innate lymphoid cells (ILCs) lack CD3 and antigen-specific receptors (131). NK cells are the best characterized ILCs (132). In blood, most NK cells express low levels of the adhesion molecule CD56 and the Ig receptor CD16. These CD56 ${ }^{\mathrm{dim}}$ cells are considered to be cytotoxic effector cells. Conversely, CD56 $6^{\text {bright }} \mathrm{NK}$ cells are much less frequent in peripheral blood and also less cytotoxic due to a low CD16 expression, suggesting that they are immunomodulatory (132). NKT cells express both a T cell receptor (TCR) and NK cell associated markers. Type I NKT cells (classical or NKT [iNKT] cells), have limited TCR diversity and recognize $\alpha$-galactosylceramide ( $\alpha$ GalCer) lipid antigens in a CDld dependent manner. Type II, or nonclassical, NKT cells are also CD1d-restricted but react to lipids other than $\alpha$ GalCer and have more diversity in their TCR repertoire (133). NKT cells can be protective in infections and auto-immune diseases and, similar to NK cells, can produce cytokines in patterns mirroring Th subsets (133).

Specialized NK cells are found in the placental decidua and are essential for successful spiral artery development and fetal implantation in the first trimester of pregnancy [reviewed in (134)]. In contrast, less is known about the effect of pregnancy on circulating NK cells (Table 3). Most studies report no change in NK subsets (CD56 ${ }^{\mathrm{dim}}, \mathrm{CD} 56^{\text {bright }}$ ), invariant NK T cells (iNKT) and type II non-classical NK T cells in peripheral blood between pregnant and non-pregnant women (135-137) despite a reduction in NK cell numbers $(138,139)$. NK cells subsets have sometimes been further divided into type 1 and type 2 immunity, depending on the cytokines they produce. By examining the surface expression of IL18R1 (type 1 immunity due to promoting IFN- $\gamma$ production) and IL1RL1 (its activation by IL-33 promotes innate immunity), the ratio of type 1 to type 2 NK cells was found to decrease in the third trimester compared to healthy controls (140). Compared to non-pregnant controls, the percentage of IL18R1 expressing cells is significantly lower in the third trimester of pregnancy. In addition, the number of IL18R1 surface molecules per cell is reduced (140). It has also been shown that homing receptor expression is increased on type 2 CD56 $6^{\text {bright }} \mathrm{NK}$ cells in the second trimester, compared to the first and third trimester. For type 2 CD $56^{\text {dim }}$ NK cells, homing receptor expression is highest in the third trimester (135). Whether this corresponds to increased migration of NK cells to the placenta at various stages during pregnancy remains to be investigated.

Maternal NK cells and monocytes have increased expression of the immune checkpoint protein TIM-3 in pregnancy (137, 141 ), potentially induced by high IL-4 and low IFN- $\gamma$ levels (143). TIM-3 is important for NK cell-mediated IFN- $\gamma$ production and may contribute to increased phagocytosis in pregnancy (143). High surface levels of TIM-3, a characteristic of lymphocyte exhaustion (144), potentially indicate that pregnancy NK cells are anergic. Plasma levels of Galectin-9 (TIM-3 ligand) are elevated throughout pregnancy (137). The high levels of this lectin may stem from a high placental production (137), however, its impact during pregnancy and whether it contributes to TIM-3 upregulation is unclear. The augmented inflammatory NK cell capacity during pregnancy is further supported by studies showing increased expression of the activation marker CD69 on CD $4^{\text {neg }}$ iNKT cells as pregnancy progresses (136). Similarly, expression of the degranulation marker LAMP-1 (CD107a) on CD56 ${ }^{\mathrm{dim}}$ cells after PMAionomycin stimulation and baseline levels of the cytotoxic markers NKp46 (CD335) and CD38 are increased in the third trimester compared to non-pregnant women (101, 137, 145). Additionally, in vitro NK cell responses to influenza-infected or cancerous cells is higher in pregnancy (145). Together, this indicates elevated baseline activity and heightened potential to upregulate pro-inflammatory responses, underlining increased innate immunity during pregnancy. In contrast, IFN- $\gamma$

TABLE 3 | Changes in systemic innate lymphoid cells during normal pregnancy. 
production is reduced and IL-10 production upon ex vivo stimulation with PMA-ionomycin is increased by NK cells from the first trimester, compared to non-pregnant women (142). This anti-inflammatory capacity could contribute to the dampening of the adaptive immune system.

Non-cytotoxic ILCs are grouped into three subtypes, ILC1, ILC2 and ILC3. These cell types have similar functions and phenotypes as Th1, Th2 and Th17, respectively (131). ILCs are found in the human placenta (146), but to the best of our knowledge, no study has assessed ILCs in other maternal tissues or blood during pregnancy.

\section{ADAPTIVE IMMUNITY}

\section{T Cells}

The absolute lymphocyte count and the percentage of total $\mathrm{T}$ cells does not differ significantly during the first, second, and third trimesters of pregnancy $(147,148)$, while the numbers of $\mathrm{T}$ cells during pregnancy are lower than before pregnancy (Table 4) (149).

Pregnancy has also been associated with changes in $\mathrm{T}$ cell subsets, although the data are conflicting and the significance is unclear (147-150). The percentages of $\mathrm{CD}^{+}$and $\mathrm{CD}^{+} \mathrm{T}$ cells of women at various stages of gestation does not differ significantly $(147,148)$. In another study, no significant changes were found in the percentage of $\mathrm{CD}^{+}$cells, $\mathrm{CD} 8^{+}$ cells, nor of $\mathrm{CD}^{+} / \mathrm{CD}^{+}$ratio at any stage of pregnancy (150). However, compared to pre-pregnancy, the number of $\mathrm{T}$ helper cells and cytotoxic T cells was lower in third and first trimesters of pregnancy, respectively, while the number of suppressor $\mathrm{T}$ cells was higher in the first trimester of pregnancy (149). At the end of the first trimester there is a surge in estrogen and progesterone, which leads to a reversible thymic involution, which could partially explain the observed decrease in both $\mathrm{CD}^{+}$and $\mathrm{CD}^{+}$cells $(196,197)$.

Studies investigated the ratio of Th2 to Th1 cells as measured by the circulatory levels of secreted Th1 or Th2 serum cytokines, or levels of $\mathrm{CD}^{+}$cells producing Th1 or Th2 cytokines, or expression of chemokine receptors CXCR3 (associated with Th1 cells) and CCR4 (associated with Th2 cells) on $\mathrm{CD} 4^{+} \mathrm{T}$ cells. The view of pregnancy as a Th2 state is supported by numerous studies (151-155), but also rejected by others (198). Viewing pregnancy as a Th2 state is supported by a rise in antiinflammatory cytokines, and by studies showing that Th1 and Th17 -type autoimmune disorders are improved (199-201) while Th2-type autoimmune disorders worsen in pregnancy (202). A progressive shift from cell-mediated, pro-inflammatory, Th1 cell responses to humoral, anti-inflammatory, Th2 cell responses is initiated early in pregnancy $(1,156)$. This pregnancy-related Th2 phenotype resolves by 4 weeks postpartum (203). The percentage of IFN- $\gamma$-producing $\mathrm{CD}^{+}$cells is lower in the third trimester while no changes in IL-4-producing $\mathrm{CD}^{+} \mathrm{T}$ cells were observed in one study (158). Other studies have found no changes in Th1/ Th2 cells during pregnancy $(158,159)$, and stable proportion of $\mathrm{CD}^{+}{ }^{+} \mathrm{CD} 8{ }^{-} \mathrm{IFN}-\gamma^{+}$cells across gestation (159). However, a recent study showed that plasma IL-2 levels (indicative of Th1 cells) were lower in the post-partum period when compared to all trimesters (157).

While pro-inflammatory cytokines (IL-1 $\beta$, IL-6, IL-8, and TNF- $\alpha$ ) increase in amniotic fluid throughout pregnancy and during labor $(204,205)$, plasmatic pro-inflammatory cytokines (e.g. IL-2 and IFN- $\gamma$ ) (206) decrease, and anti-inflammatory cytokines increase (e.g. IL-4 and IL-10) with pregnancy (175, 203). However, the numbers of IFN- $\gamma$ and IL-4 secreting cells gradually increase as the pregnancy progresses compared with postpartum (160). In contrast, a recent study showed that the percentage of resting $\mathrm{CD}^{+}{ }^{+}$cells expressing CXCR3 and CCR4 did not change significantly during different stages of pregnancy (159).

Hormones can affect the differentiation of Th cells. Serum estradiol levels increase up to 500-fold during pregnancy (175). Low estradiol promotes Th1 responses, whereas high estradiol promotes Th2 responses (1). Elevated progesterone inhibits Th1 responses during pregnancy (207) and can induce Th2-type cytokines (e.g., IL-4 and IL-5) (208) further enhancing the polarization to Th2. Moreover, progesterone may exert antiinflammatory responses as supported by higher IL-10 levels in women who received progesterone compared to placebo (209).

Th17 cells are important against extracellular bacteria or fungal pathogens (210). The ratio of Th17 cells to CD4 ${ }^{+} \mathrm{T}$ cells is similar to healthy non-pregnant women during all stages of pregnancy $(161,211)$. However, one study revealed a $60 \%$ fall in the percentage of $\mathrm{CD}^{+} \mathrm{CD} 8^{-} \mathrm{IL} 17^{+}$cells between the first and second trimesters of pregnancy (159).

Data on $\mathrm{T}$ cell function during pregnancy are scarce and inconsistent (Table 4). The methods used to measure proliferation matters in the interpretation of $\mathrm{T}$ cell function. For example, proliferation measured using ${ }^{3} \mathrm{H}$-thymidine incorporation into replicating DNA may underestimate the true proliferative response as it only detect cells in early division cycle, thus potentially missing cells that were already beyond the $\mathrm{S}$ phase of the cell cycle prior to the ${ }^{3} \mathrm{H}$-thymidine pulse (212).

\section{B Cells}

Maternal antibodies are the main maternal immune component that protect the neonate immediately after birth (213). Studies have shown that maternal B cell-produced non-cytotoxic antibodies directed against paternal antigens are detected in most women undergoing a normal pregnancy during the first trimester, whereas they are absent in a vast majority of women who experience a spontaneous abortion. This also indicates that these antibodies may be critical for a successful pregnancy (214). Peripheral blood B cell counts vary during normal pregnancy and the post-partum period, also compared to healthy non-pregnant women (Table 4) (149, 150, 165-174). A reduction in circulating B cells is particularly prominent during the third trimester, revealing a "physiological" B cell lymphopenia (175) due to the effect of elevated estrogens on lymphopoiesis $(215,216)$. This B cell lymphopenia has also been attributed to cellular migration into tissues, including the placental decidua, and suggests that B cells play a particularly important role maintaining tolerance at the maternal-fetal interface (217). In a mouse model, treatment of 
TABLE 4 | Changes in T cells, B cells, and immunoglobulins during normal pregnancy.

Component

T cells

Total levels Lower levels of T cells during pregnancy than before pregnancy.

Subsets

No differences in the absolute total lymphocyte count and the percentage of total $T$ cells during the first, second, and third trimesters.

No difference in the percentages of T helper [CD4 $\left.{ }^{+}\right]$and T suppressor [CD8 $\left.{ }^{+}\right]$cells during the first, second, and third trimesters.

No significant changes in the percentage of $\mathrm{CD} 4^{+}$cells, CD8+ cells, nor CD4 ${ }^{+} / \mathrm{CD} 8^{+}$ratio at any stage of pregnancy.

Lower number of $T$ helper cells and cytotoxic $T$ cells in third and first trimesters of pregnancy, respectively, compared to pre-

pregnancy. Higher number of suppressor $\mathrm{T}$ cells $\left(\mathrm{CD} 8^{+} \mathrm{CD} 11 \mathrm{~b}^{+}\right)$in the first trimester, compared to pre-pregnancy.

Pregnancy is associated with a Th-2 or anti-inflammatory state.

149

A progressive shift from Th1 cell responses to Th2 cell responses initiated early in pregnancy.

Lower plasma IL-2 levels (indicative of CD4 ${ }^{+}$Th1 cells) in the post-partum period when compared to all trimesters.

Lower percentage of Th1 cells $\left(\mathrm{CD} 4^{+}\right.$cells producing IFN- $\gamma$ ) in the third trimester compared to the first trimester and no changes in the percentage of Th2 (CD4 ${ }^{+}$cells producing $\left.\mathrm{LL}-4\right)$ was observed.

No change in the proportion of Th1 or Th2 cells during pregnancy. No differences in the percentage of CD $3^{+} \mathrm{CD} 8^{-}$IFN- $\gamma^{+}$cells $($Th1 phenotype) across gestation. No change in the percentage of resting CD4 ${ }^{+}$T-cells expressing CXCR3 (associated with Th1 cells) and CCR4 (associated with Th2 cells) during different stages of pregnancy.

Increase in the numbers of IFN- $\gamma$ and IL-4 secreting cells as pregnancy progressed compared with postpartum

No change in the ratio of Th17 cells to $\mathrm{CD} 4^{+} \mathrm{T}$ cells during all stages of pregnancy compared to that of healthy non-pregnant women.

Function $\quad$ Reduced PHA-Stimulated T Iymphocytes proliferation in pregnant women at various times throughout gestation compared with those from non-pregnant controls.

Decreased lymphocyte proliferation to mitogenic stimulation in the first, second and third trimesters as compared to non-pregnant women.

Decreased in IL-2 and IFN- $\gamma$ production and increased in production of IL-4 and IL-10, during normal pregnancy in response to antigen- and mitogen stimulation.

The ability of $\mathrm{T}$ cells to form colonies varied during pregnancy.

Lower numbers and/or frequency of total B cells in pregnant women compared to post-partum levels or to healthy non-pregnant women.

No changes in absolute levels of total B cells during the entire course of pregnancy.

Decrease in the absolute levels of total B cells during the entire course of pregnancy.

Subsets of B Lower frequency or total levels of $\mathrm{CD}^{+} \mathrm{B}$ cells during pregnancy, at delivery or early in the postpartum period.

cells

Lower absolute counts of transitional B cells, unswitched memory B cells, resting memory B cells, and plasmablasts during the third trimester than in non-pregnancy.

Markers of B No difference in the percentage of activated B cells during the three trimesters compared to non-pregnant women.

Subclass levels Higher lgG1 levels in the three trimesters when compared to non-pregnant women. 


\begin{tabular}{|c|c|c|}
\hline Component & Main findings & References \\
\hline & Decrease in IgM levels in the second and third trimester when compared to first trimester. & $\begin{array}{c}181,185 \\
187\end{array}$ \\
\hline & Increase in total IgM levels during late-third (36-42 WG) compared with early-third (27-33 WG) trimester. & 185, 195 \\
\hline & Increase in total lgM levels in the first trimester as compared to non-pregnant women & 178 \\
\hline & No difference in IgM levels in the third trimester compared to non-pregnant women. & 179 \\
\hline \multicolumn{3}{|c|}{$\mathrm{T}$} \\
\hline Total levels & No change in lgE levels during the course of pregnancy. & 178 \\
\hline
\end{tabular}

IFN- $\gamma$, Interferon- $\gamma$, Th, Thelper; PHA, Phytohemagglutinin; IgG, immunoglobulin G; FC, fragment crystallization; IgA, immunoglobulin A; IgM, immunoglobulin M; IgE, immunoglobulin E.

mice with estrogen upregulated expression of CD22 receptor and the intracellular tyrosine phosphatase SHP-1 genes in B cells. Overexpression of these genes led to diminished calcium response in $\mathrm{B}$ cells after activation of $\mathrm{BCR}$, thus supporting a role of these molecules in reduction in $\mathrm{B}$ cell receptor signaling (218).

Pregnancy is also associated with changes in B cell subsets, specifically lower innate B-l cells during pregnancy until delivery and during the early postpartum period $(149,165,169,173)$. B-1 cells are the major source of "innate" IgM antibodies, playing a protective role in the early stage after infection (219).

The function of B cells also decreases as pregnancy advances. Loss of responsiveness to mitogens and infectious agents, which may increase the risk of infection, has been reported (Table 4) (180). Analyses of serum markers of B cell function and activation such as soluble CD23 (sCD23) and B cell activating factor (BAFF) provide further insights into changes in $\mathrm{B}$ cell biology during pregnancy. CD23 is expressed on earliest B cells exiting the bone marrow while the post-germinal center $\mathrm{B}$ cells are CD23 negative. Following B cell activation, CD23 is cleaved and thus sCD23 levels, which are stable for 12-24 h, are a marker of the turnover from naïve to memory B Cells (MBC) (220). In non-pregnant populations, high sCD23 has been associated with inflammatory and lymphoprolifertiave disorders $(221,222)$, and relapse of rheumatoid arthritis (223). Plasma levels of sCD23 levels decrease during the third trimester of pregnancy (179), suggesting lower turnover from naïve to $\mathrm{MBCs}$ and may reflect an antiinflammatory state in pregnancy. BAFF expression in trophoblasts and decidua has been associated with early recurrent spontaneous abortion (224). Plasma levels of BAFF increase during the third trimester (179), suggesting that BAFF may play an important role in the implantation of the embryo. Moreover, peripheral B cell levels are inversely correlated with serum BAFF levels in patients with rheumatoid arthritis receiving $B$ cell depletion therapy or who have primary antibody deficiencies $(223,225)$. Thus, this increase of BAFF levels in the third trimester of pregnancy supports the note of a decrease in the total B cell pool in late pregnancy.

\section{Immunoglobulins}

Studies from the 1960s-1970s reported conflicting results regarding immunoglobulin (Ig) levels during pregnancy (Table 4). Some studies suggest that total IgG levels remain stable during pregnancy (181-183), while other studies show a decrease in late pregnancy $(179,184-189)$. IgG1 levels were higher in pregnancy compared to non-pregnant women, while IgG3 levels were higher in pregnant women in their second trimester, compared to non-pregnant women (178). IgG1 is the subclass that is most efficiently trans-placentally transferred to the newborn and is a stronger inducer of Fc-mediated effector mechanisms (e.g. antibody-dependent cellular cytotoxicity, complement dependent cytotoxicity, and antibody-dependent cellular phagocytosis (226), thus potentially providing critical protection for both the mother and the infant in early life. IgG2 and IgG4 levels remain stable during pregnancy and levels are comparable to non-pregnant women (178). The seemingly discrepant results of lower total IgG levels and changes in subclasses (higher IgG1 and IgG3, comparable IgG2 and IgG4), emphasize the challenges of interpreting and comparing results from different cohorts using different immunological assays. Another important caveat to these studies is that measuring antibody concentrations only certainly does not fully account for functional antibody changes unless other characteristics are examined, including avidity and more recently structural changes such as glycosylation that enhance antibody functions (227, 228).

IgGs are glycoproteins and contain $\mathrm{N}$-glycans at both the $\mathrm{Fc}$ and Fab portion of IgGs. These N-glycans consist of a constant heptasaccharide core, fucose, $\mathrm{N}$ acetylglucosamine (GlcNAc), galactose(s), and sialic acid(s) (190, 229). Pregnancy has been shown to be associated with changes in IgG Fc domain glycosylation, with an increase of galactosylation and sialylation of the Fc portion of IgG (190-192), whereas Fc fucosylation was shown to remain at high and very similar levels during pregnancy (190, 192). IgG Fc domain glycosylation can have immune regulatory functions and modulate IgG effector functions as Fc-linked glycans alter the three-dimensional structure of the protein, thus influencing the binding to Fcreceptors (230, 231). Glycan-glycan interactions occur between IgG and Fc Receptor IIIa (232), with core fucose decreasing the affinity of this interaction (233). Thus, high fucosylation of the Fc portion of the $\operatorname{IgG}$, that is reported to occur during pregnancy, has the potential to inhibit the binding with Fc Receptor IIIa expressed on NK cells, and thus decreasing ADCC activity, suggesting that this post-translational modification might be associated with an increased risk for infections in pregnancy.

Asymmetric IgG are characterized by the presence of an oligosaccharide group of the high mannose type in only one of the two Fab fragments and are present in mammalian sera in 
$\sim 15 \%$ of total IgG. These antibodies are thought to act locally at the placental level to block placental antigens, thus preventing immunological attack by maternal natural killer (NK) cells and cytotoxic lymphocytes (193). Interestingly, pregnancy is associated with an increase in asymmetric IgG antibodies (193, 194).

While some evidence, mainly from the 1960s-1970s support that there is no significant change in IgA levels during pregnancy $(166,182,183,186,189)$, other data suggest more dynamic changes to occur during pregnancy $(178,179,187)$. Data on IgM levels during pregnancy are conflicting $(166,178,179,181,182$, 184-187, 195). Scarce data show that IgE levels remain stable during pregnancy (Table 4) (178).

Different factors could explain a decrease of total Ig levels in pregnancy including depression of cell-mediated immunity, loss of protein in urine, hemodilution, transfer of IgG from mother to fetus across the placenta, or pregnancy-associated hormones, especially steroid hormones, which have effects on protein synthesis $(234,235)$. Hemodilution due to increased intravascular volume during pregnancy might explain the low Ig levels. However, one small study showed that although total IgG, IgM and IgA levels decreased from the first trimester to second trimester and in the third trimester also for IgG as compared to first trimester, this decrease was also accompanied by a decrease in the ratio of total $\mathrm{IgG}$ to serum protein in the second and third trimester, thus supporting that there is a true decrease in serum Ig levels not attributed only to a decrease in serum protein (187).

\section{T Regulatory Cells}

$\mathrm{T}$ regulatory cells (Tregs) induce peripheral tolerance by suppressing the proliferation and cytokine production of CD4 and CD8 T cells, Ig production by B cells, cytotoxic activity of NK cells, and maturation of dendritic cells $(236,237)$. Tregs express low levels of IL7R and high levels of the alpha chain of IL-2 receptor (CD25) (238) and the transcription factor Forkhead box p3 (Foxp3) (239). Other suppressive T cell subsets have been described (240) including, CD $4^{+} \mathrm{CD} 25^{+}$Foxp3type 1 regulatory T cells $(\mathrm{Tr} 1)$, and $\mathrm{CD} 4^{+} \mathrm{CD} 25^{\text {low }} \mathrm{Th} 3$ cells $(241$, 242) that are induced by, and exert their suppressive activity through IL-10 (243) and TGF- $\beta$ (244).
Tregs are important in regulating fetal rejection by maternal immune cells (245) and to suppress inflammation in the uterus during the implantation period $(238,246-249)$. The dynamics of Tregs during pregnancy are controversial, which might be in part due to difference in how Tregs are defined between studies (Table 5). Estrogen augmented Foxp3 expression in vitro and in vivo, and treatment with estrogen increased $\mathrm{CD} 4^{+} \mathrm{CD} 25^{+}$ "Tregs" in animal model, potential promoting maternal fetal tolerance (254). A decline in peripheral blood CD $25^{\text {bright }} \mathrm{CD} 4^{+} \mathrm{T}$ cells was reported in pregnant women with spontaneous abortion compared to uncomplicated pregnancies (249) and compared to women with elective abortion (249, 255). However, because activated $\mathrm{T}$ cells also express CD25 this choice of markers may have led to overclassifying Treg. While CD25 and Foxp3 are often used as Treg markers, activated conventional $\mathrm{T}$ cells can also express Foxp 3 in addition to dim levels of CD25 $(256,257)$. In one study, a higher percentage of $\mathrm{CD} 4{ }^{+} \mathrm{CD} 25^{\mathrm{dim}} \mathrm{T}$ cells was observed at term as compared to $17-$ 24 weeks into gestation, however, no significant changes were observed in $\mathrm{CD} 4^{+} \mathrm{CD} 25^{\text {bright }} \mathrm{T}$ cells (251). In another study, the number of $\mathrm{CD} 4{ }^{+} \mathrm{CD} 25^{+} \mathrm{FoxP}^{+} \mathrm{T}$ cells decreased during the first trimester then increased at 24-30 weeks of gestation then again declined after 31 weeks until term (252). Some studies showed that the proportion of Tregs in circulation increases during early pregnancy $(238,249)$ and peaks in the second trimester $(238$, 250), with one study showing that these cells express Foxp3 (238) to further support that they are Tregs (Table 5). However, in the latter studies $(238,250)$, no distinction between $\mathrm{CD} 4^{+} \mathrm{CD} 25^{\mathrm{dim}}$ and $\mathrm{CD} 4^{+} \mathrm{CD} 25^{\text {bright }} \mathrm{T}$ cells was made, thus limiting the definite conclusion about the true dynamics of Tregs during human pregnancy. Comparing different Treg characterization methods, both $\mathrm{CD} 4^{+} \mathrm{CD} 25^{\text {bright }}$ and $\mathrm{CD} 4^{+} \mathrm{CD} 127^{\text {low }} \mathrm{CD} 25^{+} \mathrm{T}$ cells subsets were significantly elevated at the time of delivery compared to non-pregnant women (258). CD $4^{+} \mathrm{Foxp}^{+} \mathrm{T}$ cell proportions were also higher but not statistically significant. Further work is required to truly understand the dynamics of blood regulatory $\mathrm{T}$ cells in human pregnancy.

\section{B Regulatory Cells}

B regulatory cells (Bregs) express high levels of CD24, CD27, and/or CD38, and have the capacity to suppress $\mathrm{T}$ cell responses in part through production of the anti-inflammatory cytokine

TABLE 5 | Changes in systemic T- and B- regulatory cells during normal pregnancy.

\begin{tabular}{|c|c|c|}
\hline Component & Main Findings & References \\
\hline \multicolumn{3}{|c|}{$\mathrm{T}$ regulatory cells } \\
\hline & Increased proportion of T regulatory cells during early pregnancy, peaking in the second trimester and declining in the third trimester. & 238,250 \\
\hline & $\begin{array}{l}\text { Higher percentage of } \mathrm{CD} 4^{+} \mathrm{CD} 25^{\text {dim }} \mathrm{T} \text { cells in samples obtained at term (>37 weeks) as compared to } 17-24 \text { weeks, while no significant } \\
\text { changes in } \mathrm{CD} 4^{+} \mathrm{CD} 25^{\text {bright }} T \text { cells. }\end{array}$ & 251 \\
\hline & Increased $\mathrm{CD} 4^{+} \mathrm{CD} 25^{\text {bright }} \mathrm{T}$ cells during early pregnancy compared to non-pregnant women, from 6\% to $8 \%$. & 249 \\
\hline & $\begin{array}{l}\text { Decreased number of } \mathrm{CD}^{+}{ }^{+} \mathrm{CD} 25^{+} \mathrm{FoxP}^{+} \mathrm{T} \text { cells from } 5 \text { to } 23 \text { weeks gestation, then increased during 24-30 weeks gestation, then } \\
\text { declined after } 31 \text { weeks until term. }\end{array}$ & 252 \\
\hline \multicolumn{3}{|c|}{ B regulatory cells } \\
\hline & $\begin{array}{l}\text { Lower absolute levels of IL-10-producing B cells and CD } 24^{\text {hi }} C D 38^{\text {hi }} B \text { regulatory cells during the third trimester and on delivery day than } \\
\text { those in the post-partum women. }\end{array}$ & 174 \\
\hline & Increased $\mathrm{CD} 19^{+} \mathrm{CD} 24^{\mathrm{hi}} \mathrm{CD} 27^{+} \mathrm{B}$ cells in the first trimester as compared to non-pregnant women. & 253 \\
\hline
\end{tabular}


IL-10 (259-261). Breg-specific transcription factors have not been identified and there is phenotypic heterogeneity of Bregs indicating that Bregs may not represent a distinct lineage (262). $\mathrm{CD} 19^{+} \mathrm{CD} 24^{\mathrm{hi}} \mathrm{CD} 27^{+}$Breg levels increase in the first trimester of pregnancy (253) (Table 5). Human chorionic gonadotropin (hCG) enhances the function of Bregs as hCG induces IL-10 production in $\mathrm{B}$ cells and $\sim 95 \% \mathrm{CD} 19^{+} \mathrm{CD} 24^{\mathrm{hi}} \mathrm{CD} 27^{+}$cells expressed the hCG receptor (253). Absolute counts of IL-10producing Bregs and $\mathrm{CD} 24{ }^{\text {hi }} \mathrm{CD} 38^{\text {hi }}$ Bregs are lower during the third trimester and at delivery than in women post-partum (174). Bregs' main role during pregnancy may be to suppress maternal Th1 responses, thus preventing allogeneic responses against the fetus (253). However, the full mechanism behind the activation and expansion of Bregs in pregnancy remain unclear.

\section{MATERNAL IMMUNE PATHOLOGY DRIVING ADVERSE PREGNANCY OUTCOMES}

In this review, we have described how the maternal immune system undergoes major adaptation during a healthy pregnancy. Failure to induce these systemic changes predisposes women to adverse pregnancy outcomes and this may be more likely in women with underlying autoimmune diseases. Women with Systemic Lupus Erythematosus (SLE) are at a disproportionately high risk for pregnancy complications. Preterm birth occurs three times more often and post-partum infections are over four times more likely in pregnant women with SLE than in healthy women (263). Using whole blood transcriptomics, Hong et al. found that while signatures specific to SLE (e.g. elevated interferon responses) are retained, changes seen in healthy women's pregnancies are surprisingly well recapitulated in SLE patients with uncomplicated pregnancies (264). However, in SLE patients with pregnancy complications, certain transcriptomic modules (e.g. plasma cell signatures) were not downregulated to the same extent as in healthy or uncomplicated SLE pregnancies.

While fetal and maternal obstetric outcomes are often adversely affected by autoimmune diseases, the disease severity or risk of relapse is often reduced during pregnancy. This is especially true for Th1 mediated autoimmune diseases such as rheumatoid arthritis (RA) and multiple sclerosis (MS) whereas Th2 mediated diseases such neuromyelitis optica spectrum disorders worsens during pregnancy [reviewed in (265)]. This dichotomy is attributed to the shift towards Th2 based immunity during pregnancy. Concomitant with the return to pre-pregnancy hormone levels and immune status in the post-partum period, many women affected by RA or MS experience a relapse and worsening of symptoms $(266,267)$. A better understanding of how specific alterations in the maternal immune system during pregnancy lead to symptom improvement could help guide the development of novel therapeutics in autoimmune diseases.

\section{CONCLUSIONS AND FUTURE DIRECTIONS}

In conclusion, a large body of scientific literature that accumulated over years demonstrates significant systemic

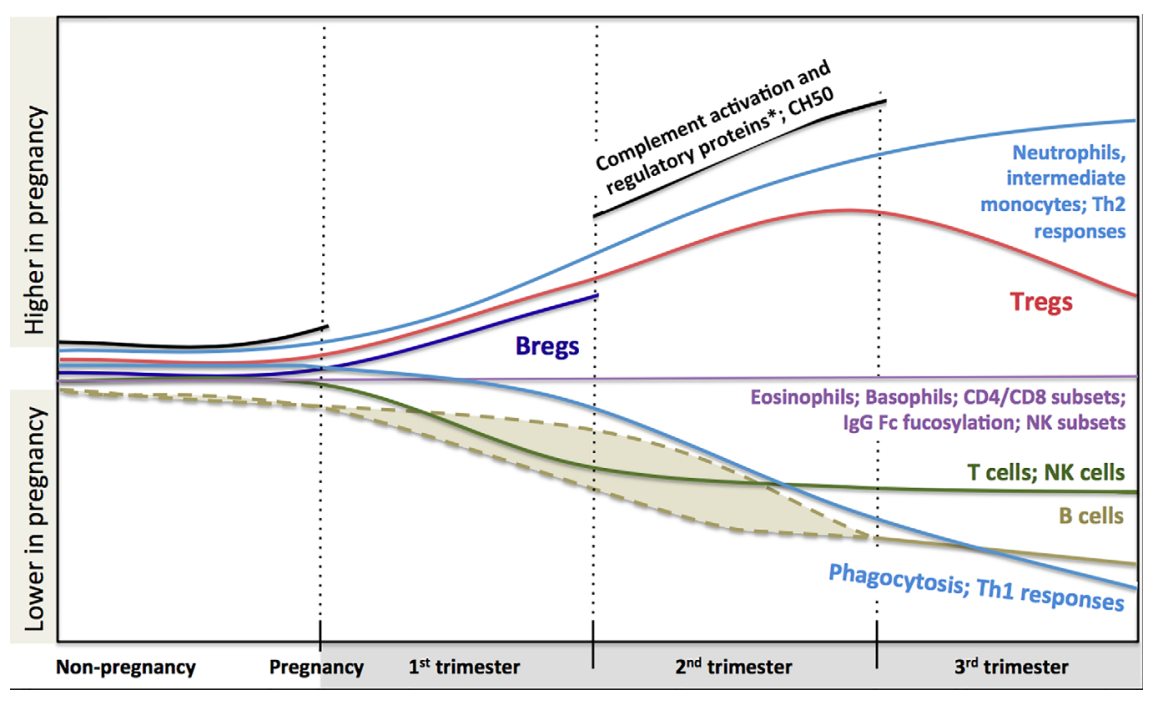

FIGURE 1 | Changes in maternal immune system components during pregnancy based on current literature. Trimester-specific changes that are not described in the literature are not shown and represented as gaps and stops in lines (i.e. complement activation and regulatory proteins, $\mathrm{CH} 50$ and $\mathrm{B}$ regulatory cells). Dashed lines indicate that reduction in B cell might happen during first or second trimester. There are controversies in the literature regarding the dynamics of total and subclasses of IgG combined to draw a definite pattern (thus it is not described in the figure, see full text for details). Fucosylation of Fc portion of IgG is similar to non-pregnancy but at very high levels. ${ }^{*}$ Complement activation proteins: C3a, C4a, C5a, Serum Complement Membrane Attack Complex SC5b9; Complement regulatory proteins: Decay-accelerating factor (CD55), C3 inhibitor pregnancy-associated plasma protein A. 
immunological adaptation during pregnancy (Figure 1). The changes indicate highly dynamic co-operative interactions between the maternal and fetal immune system, rather than a broad maternal immune suppression. Knowledge of these changes is helpful to interpret clinical immunology testing results. However, despite all these data, we still lack a clear understanding of how these immunological changes contribute to modulation of the risk of infection and the course of immunological disease during pregnancy. Also, pregnancy remains one of the most vulnerable periods in terms of morbidity and mortality, certainly for the fetus, but also for the mother. Indeed, sepsis alone accounts for about $12.5 \%$ of all deaths in women during or within 42 days of the end of pregnancy in the US (268). Major concurrent physiological (e.g. circulatory changes, increased abdominal pressure) and endocrinological changes clearly modulate these risks. Yet, teasing out the specific contribution of immunological changes on pregnancy outcomes will require more considerate approaches. Systems immunology can integrate a large amount of information in an unbiased way. When coupled to detailed clinical outcomes, these studies have proven extremely valuable in human health research where classic experimental approaches

\section{REFERENCES}

1. Kourtis AP, Read JS, Jamieson DJ. Pregnancy and infection. $N$ Engl J Med (2014) 370:2211-8. doi: 10.1056/NEJMra1213566

2. Schnarr J, Smaill F. Asymptomatic bacteriuria and symptomatic urinary tract infections in pregnancy. Eur J Clin Invest (2008) 38(Suppl 2):50-7. doi: 10.1111/j.1365-2362.2008.02009.x

3. Sheffield JS, Cunningham FG. Community-acquired pneumonia in pregnancy. Obstet Gynecol (2009) 114:915-22. doi: 10.1097/ AOG.0b013e3181b8e76d

4. Jackson KA, Iwamoto M, Swerdlow D. Pregnancy-associated listeriosis. Epidemiol Infect (2010) 138:1503-9. doi: 10.1017/S0950268810000294

5. Gellin BG, Broome CV, Bibb WF, Weaver RE, Gaventa S, Mascola L. The epidemiology of listeriosis in the United States-1986. Listeriosis Study Group. Am J Epidemiol (1991) 133:392-401. doi: 10.1093/ oxfordjournals.aje.a115893

6. Schuchat A, Deaver KA, Wenger JD, Plikaytis BD, Mascola L, Pinner RW, et al. Role of foods in sporadic listeriosis. I. Case-control study of dietary risk factors. The Listeria Study Group. JAMA (1992) 267:2041-5. doi: 10.1001/ jama.267.15.2041

7. MacDonald PD, Whitwam RE, Boggs JD, MacCormack JN, Anderson KL, Reardon JW, et al. Outbreak of listeriosis among Mexican immigrants as a result of consumption of illicitly produced Mexican-style cheese. Clin Infect Dis (2005) 40:677-82. doi: 10.1086/427803

8. Silk BJ, Date KA, Jackson KA, Pouillot R, Holt KG, Graves LM, et al. Invasive listeriosis in the Foodborne Diseases Active Surveillance Network (FoodNet), 2004-2009: further targeted prevention needed for higher-risk groups. Clin Infect Dis (2012) 54(Suppl 5):S396-404. doi: 10.1093/cid/ cis 268

9. Mylonakis E, Paliou M, Hohmann EL, Calderwood SB, Wing EJ. Listeriosis during pregnancy: a case series and review of 222 cases. Med (Baltimore) (2002) 81:260-9. doi: 10.1097/00005792-200207000-00002

10. Goulet V, Hebert M, Hedberg C, Laurent E, Vaillant V, De Valk H, et al. Incidence of listeriosis and related mortality among groups at risk of acquiring listeriosis. Clin Infect Dis (2012) 54:652-60. doi: 10.1093/cid/ cir902

11. Cheng VC, Woo PC, Lau SK, Cheung CH, Yung RW, Yam LY, et al. Peripartum tuberculosis as a form of immunorestitution disease. Eur J Clin Microbiol Infect Dis (2003) 22:313-7. doi: 10.1007/s10096-003-0927-1 are not feasible for obvious ethical reasons (269). Most recently, multiparameter analyses incorporating blood counts, flow cytometry and proteomics, identified immunological changes tightly linked to fetal development stages (270). These approaches may also help understand whether and how specific Th2-mediated autoimmune conditions may worsen, while some immune-mediated diseases improve clinically during pregnancy as described above. Systems immunology may also provide insights into the early life origins of allergic sensitization (271) and the optimization of maternal vaccination schedules to best protect both the mother and her infant. In the end, the potential for these unbiased human immunology approaches to inform therapeutic interventions during pregnancy is enormous, but will require concerted efforts from clinicians, biostatisticians, epidemiologists and molecular immunologists.

\section{AUTHOR CONTRIBUTIONS}

BA drafted the adaptive immune system section and CM drafted the innate immune system section. All authors contributed to the article and approved the submitted version.

12. Zenner D, Kruijshaar ME, Andrews N, Abubakar I. Risk of tuberculosis in pregnancy: a national, primary care-based cohort and self-controlled case series study. Am J Respir Crit Care Med (2012) 185:779-84. doi: 10.1164/ rccm.201106-1083OC

13. Okoko BJ, Enwere G, Ota MO. The epidemiology and consequences of maternal malaria: a review of immunological basis. Acta Trop (2003) 87:193-205. doi: 10.1016/s0001-706x(03)00097-4

14. Rijken MJ, McGready R, Boel ME, Poespoprodjo R, Singh N, Syafruddin D, et al. Malaria in pregnancy in the Asia-Pacific region. Lancet Infect Dis (2012) 12:75-88. doi: 10.1016/S1473-3099(11)70315-2

15. McGregor IA. Epidemiology, malaria and pregnancy. Am J Trop Med Hyg (1984) 33:517-25. doi: 10.4269/ajtmh.1984.33.517

16. Taylor SM, van Eijk AM, Hand CC, Mwandagalirwa K, Messina JP, Tshefu AK, et al. Quantification of the burden and consequences of pregnancyassociated malaria in the Democratic Republic of the Congo. J Infect Dis (2011) 204:1762-71. doi: 10.1093/infdis/jir625

17. Siston AM, Rasmussen SA, Honein MA, Fry AM, Seib K, Callaghan WM, et al. Pandemic 2009 influenza A(H1N1) virus illness among pregnant women in the United States. JAMA (2010) 303:1517-25. doi: 10.1001/ jama.2010.479

18. Rasmussen SA, Jamieson DJ, Bresee JS. Pandemic influenza and pregnant women. Emerg Infect Dis (2008) 14:95-100. doi: 10.3201/eid1401.070667

19. Mosby LG, Rasmussen SA, Jamieson DJ. 2009 pandemic influenza A (H1N1) in pregnancy: a systematic review of the literature. Am J Obstet Gynecol (2011) 205:10-8. doi: 10.1016/j.ajog.2010.12.033

20. Dodds L, McNeil SA, Fell DB, Allen VM, Coombs A, Scott J, et al. Impact of influenza exposure on rates of hospital admissions and physician visits because of respiratory illness among pregnant women. CMAJ (2007) 176:463-8. doi: 10.1503/cmaj.061435

21. Neuzil KM, Reed GW, Mitchel EF, Simonsen L, Griffin MR. Impact of influenza on acute cardiopulmonary hospitalizations in pregnant women. Am J Epidemiol (1998) 148:1094-102. doi: 10.1093/oxfordjournals. aje.a009587

22. Freeman DW, Barno A. Deaths from Asian influenza associated with pregnancy. Am J Obstet Gynecol (1959) 78:1172-5. doi: 10.1016/0002-9378 (59)90570-8

23. Triebwasser JH, Harris RE, Bryant RE, Rhoades ER. Varicella pneumonia in adults. Report of seven cases and a review of literature. Med (Baltimore) (1967) 46:409-23. doi: 10.1097/00005792-196709000-00003 
24. Lamont RF, Sobel JD, Carrington D, Mazaki-Tovi S, Kusanovic JP, Vaisbuch E, et al. Varicella-zoster virus (chickenpox) infection in pregnancy. BJOG (2011) 118:1155-62. doi: 10.1111/j.1471-0528.2011.02983.x

25. Paryani SG, Arvin AM. Intrauterine infection with varicella-zoster virus after maternal varicella. N Engl J Med (1986) 314:1542-6. doi: 10.1056/ NEJM198606123142403

26. Haake DA, Zakowski PC, Haake DL, Bryson YJ. Early treatment with acyclovir for varicella pneumonia in otherwise healthy adults: retrospective controlled study and review. Rev Infect Dis (1990) 12:788-98. doi: $10.1093 /$ clinids/12.5.788

27. Esmonde TF, Herdman G, Anderson G. Chickenpox pneumonia: an association with pregnancy. Thorax (1989) 44:812-5. doi: 10.1136/ thx.44.10.812

28. Patra S, Kumar A, Trivedi SS, Puri M, Sarin SK. Maternal and fetal outcomes in pregnant women with acute hepatitis $\mathrm{E}$ virus infection. Ann Intern Med (2007) 147:28-33. doi: 10.7326/0003-4819-147-1-200707030-00005

29. Kumar A, Beniwal M, Kar P, Sharma JB, Murthy NS. Hepatitis E in pregnancy. Int J Gynaecol Obstet (2004) 85:240-4. doi: 10.1016/ j.ijgo.2003.11.018

30. Khuroo MS, Kamili S. Aetiology and prognostic factors in acute liver failure in India. J Viral Hepat (2003) 10:224-31. doi: 10.1046/j.13652893.2003.00415.x

31. Aggarwal R, Krawczynski K. Hepatitis E: an overview and recent advances in clinical and laboratory research. J Gastroenterol Hepatol (2000) 15:9-20. doi: 10.1046/j.1440-1746.2000.02006.x

32. Anya SE. Seasonal variation in the risk and causes of maternal death in the Gambia: malaria appears to be an important factor. Am J Trop Med Hyg (2004) 70:510-3. doi: 10.4269/ajtmh.2004.70.510

33. Desai M, ter Kuile FO, Nosten F, McGready R, Asamoa K, Brabin B, et al. Epidemiology and burden of malaria in pregnancy. Lancet Infect Dis (2007) 7:93-104. doi: 10.1016/S1473-3099(07)70021-X

34. Rogerson SJ. Malaria in pregnancy and the newborn. Adv Exp Med Biol (2010) 659:139-52. doi: 10.1007/978-1-4419-0981-7_12

35. Menendez C. Malaria during pregnancy. Curr Mol Med (2006) 6:269-73. doi: $10.2174 / 156652406776055186$

36. Collins S, Ramsay M, Slack MP, Campbell H, Flynn S, Litt D, et al. Risk of invasive Haemophilus influenzae infection during pregnancy and association with adverse fetal outcomes. JAMA (2014) 311:1125-32. doi: 10.1001/jama.2014.1878

37. Berndsen MR, Erlendsdóttir H, Gottfredsson M. Evolving epidemiology of invasive Haemophilus infections in the post-vaccination era: results from a long-term population-based study. Clin Microbiol Infect (2012) 18:918-23. doi: 10.1111/j.1469-0691.2011.03700.x

38. Perdue DG, Bulkow LR, Gellin BG, Davidson M, Petersen KM, Singleton RJ, et al. Invasive Haemophilus influenzae disease in Alaskan residents aged 10 years and older before and after infant vaccination programs. JAMA (2000) 283:3089-94. doi: 10.1001/jama.283.23.3089

39. Deutscher M, Lewis M, Zell ER, Taylor TH, Van Beneden C, Schrag S, et al. Incidence and severity of invasive Streptococcus pneumoniae, group A Streptococcus, and group B Streptococcus infections among pregnant and postpartum women. Clin Infect Dis (2011) 53:114-23. doi: 10.1093/cid/cir325

40. Machado CR, Machado ES, Rohloff RD, Azevedo M, Campos DP, de Oliveira RB, et al. Is pregnancy associated with severe dengue? A review of data from the Rio de Janeiro surveillance information system. PLoS Negl Trop Dis (2013) 7:e2217. doi: 10.1371/journal.pntd.0002217

41. White SR, Henretig FM, Dukes RG. Medical management of vulnerable populations and co-morbid conditions of victims of bioterrorism. Emerg Med Clin North Am (2002) 20:365-92, xi. doi: 10.1016/S0733-8627(01) 00006-2

42. Price ME, Fisher-Hoch SP, Craven RB, McCormick JB. A prospective study of maternal and fetal outcome in acute Lassa fever infection during pregnancy. BMJ (1988) 297:584-7. doi: 10.1136/bmj.297.6648.584

43. Kang AH, Graves CR. Herpes simplex hepatitis in pregnancy: a case report and review of the literature. Obstet Gynecol Surv (1999) 54:463-8. doi: 10.1097/00006254-199907000-00026

44. Chase RA, Pottage JC, Haber MH, Kistler G, Jensen D, Levin S. Herpes simplex viral hepatitis in adults: two case reports and review of the literature. Rev Infect Dis (1987) 9:329-33. doi: 10.1093/clinids/9.2.329
45. Yaziji H, Hill T, Pitman TC, Cook CR, Schrodt GR. Gestational herpes simplex virus hepatitis. South Med J (1997) 90:347-51. doi: 10.1097/ 00007611-199703000-00019

46. Smale LE, Waechter KG. Dissemination of coccidioidomycosis in pregnancy. Am J Obstet Gynecol (1970) 107:356-61. doi: 10.1016/00029378(70)90557-0

47. Vaughan JE, Ramirez H. Coccidioidomycosis as a complication of pregnancy. Calif Med (1951) 74:121-5.

48. Bercovitch RS, Catanzaro A, Schwartz BS, Pappagianis D, Watts DH, Ampel NM. Coccidioidomycosis during pregnancy: a review and recommendations for management. Clin Infect Dis (2011) 53:363-8. doi: 10.1093/cid/cir410

49. Wack EE, Ampel NM, Galgiani JN, Bronnimann DA. Coccidioidomycosis during pregnancy. An analysis of ten cases among 47,120 pregnancies. Chest (1988) 94:376-9. doi: 10.1378/chest.94.2.376

50. Caldwell JW, Arsura EL, Kilgore WB, Garcia AL, Reddy V, Johnson RH. Coccidioidomycosis in pregnancy during an epidemic in California. Obstet Gynecol (2000) 95:236-9. doi: 10.1097/00006250-200002000-00013

51. Eberhart-Phillips JE, Frederick PD, Baron RC, Mascola L. Measles in pregnancy: a descriptive study of 58 cases. Obstet Gynecol (1993) 82:797-801.

52. Ali ME, Albar HM. Measles in pregnancy: maternal morbidity and perinatal outcome. Int J Gynaecol Obstet (1997) 59:109-13. doi: 10.1016/s0020-7292 (97)00196-3

53. Sever JL, Ellenberg JH, Ley AC, Madden DL, Fuccillo DA, Tzan NR, et al. Toxoplasmosis: maternal and pediatric findings in 23,000 pregnancies. Pediatrics (1988) 82:181-92.

54. Desmonts G, Couvreur J. Congenital toxoplasmosis. A prospective study of 378 pregnancies. N Engl J Med (1974) 290:1110-6. doi: 10.1056/ NEJM197405162902003

55. Rasmussen SA, Jamieson DJ, Uyeki TM. Effects of influenza on pregnant women and infants. Am J Obstet Gynecol (2012) 207:S3-8. doi: 10.1016/ j.ajog.2012.06.068

56. Louie JK, Acosta M, Jamieson DJ, Honein MA, Group CPHNW. Severe 2009 $\mathrm{H} 1 \mathrm{~N} 1$ influenza in pregnant and postpartum women in California. $\mathrm{N} \mathrm{Engl} \mathrm{J}$ Med (2010) 362:27-35. doi: 10.1056/NEJMoa0910444

57. Jamieson DJ, Theiler RN, Rasmussen SA. Emerging infections and pregnancy. Emerg Infect Dis (2006) 12:1638-43. doi: 10.3201/eid1211.060152

58. Lindsay L, Jackson LA, Savitz DA, Weber DJ, Koch GG, Kong L, et al. Community influenza activity and risk of acute influenza-like illness episodes among healthy unvaccinated pregnant and postpartum women. Am J Epidemiol (2006) 163:838-48. doi: 10.1093/aje/kwj095

59. Pastuszak AL, Levy M, Schick B, Zuber C, Feldkamp M, Gladstone J, et al. Outcome after maternal varicella infection in the first 20 weeks of pregnancy. N Engl J Med (1994) 330:901-5. doi: 10.1056/NEJM199403313301305

60. (CDC). Rubella and congenital rubella syndrome control and elimination global progress, 2000-2012. MMWR Morb Mortal Wkly Rep (2013) 62:983-6.

61. Siegel M, Fuerst HT. Low birth weight and maternal virus diseases. A prospective study of rubella, measles, mumps, chickenpox, and hepatitis. JAMA (1966) 197:680-4. doi: 10.1001/jama.197.9.680

62. (CDC). Three cases of congenital rubella syndrome in the postelimination era-Maryland, Alabama, and Illinois, 2012. MMWR Morb Mortal Wkly Rep (2013) 62:226-9.

63. Dijkmans AC, de Jong EP, Dijkmans BA, Lopriore E, Vossen A, Walther FJ, et al. Parvovirus B19 in pregnancy: prenatal diagnosis and management of fetal complications. Curr Opin Obstet Gynecol (2012) 24:95-101. doi: 10.1097/GCO.0b013e3283505a9d

64. Lamont RF, Sobel J, Mazaki-Tovi S, Kusanovic JP, Vaisbuch E, Kim SK, et al. Listeriosis in human pregnancy: A systematic review. J Perinatal Med (2011) 39:227-36. doi: 10.1515/jpm.2011.035

65. Smith B, Kemp M, Ethelberg S, Schiellerup P, Bruun BG, Gerner-Smidt P, et al. Listeria monocytogenes: maternal-foetal infections in Denmark 19942005. Scand J Infect Dis (2009) 41:21-5. doi: 10.1080/00365540802468094

66. Peng W, Yang J, Liu E. Analysis of 170 cases of congenital TB reported in the literature between 1946 and 2009. Pediatr Pulmonol (2011) 46:1215-24. doi: 10.1002/ppul.21490

67. Jana N, Vasishta K, Saha SC, Ghosh K. Obstetrical outcomes among women with extrapulmonary tuberculosis. N Engl J Med (1999) 341:645-9. doi: 10.1056/NEJM199908263410903 
68. Meaney-Delman D, Hills SL, Williams C, Galang RR, Iyengar P, Hennenfent AK, et al. Zika Virus Infection Among U.S. Pregnant Travelers - August 2015-February 2016. MMWR Morb Mortal Wkly Rep (2016) 65:211-4. doi: 10.15585/mmwr.mm6508e1

69. Rasmussen SA, Jamieson DJ, Honein MA, Petersen LR. Zika Virus and Birth Defects-Reviewing the Evidence for Causality. N Engl J Med (2016) 374:1981-7. doi: 10.1056/NEJMsr1604338

70. Siegel M, Fuerst HT, Peress NS. Comparative fetal mortality in maternal virus diseases. A prospective study on rubella, measles, mumps, chicken pox and hepatitis. N Engl J Med (1966) 274:768-71. doi: 10.1056/ NEJM196604072741404

71. Atmar RL, Englund JA, Hammill H. Complications of measles during pregnancy. Clin Infect Dis (1992) 14:217-26. doi: 10.1093/clinids/14.1.217

72. Dollard SC, Grosse SD, Ross DS. New estimates of the prevalence of neurological and sensory sequelae and mortality associated with congenital cytomegalovirus infection. Rev Med Virol (2007) 17:355-63. doi: $10.1002 /$ rmv.544

73. Abu Raya B, Edwards KM, Scheifele DW, Halperin SA. Pertussis and influenza immunisation during pregnancy: a landscape review. Lancet Infect Dis (2017) 17:e209-e22. doi: 10.1016/S1473-3099(17)30190-1

74. Ander SE, Diamond MS, Coyne CB. Immune responses at the maternal-fetal interface. Sci Immunol (2019) 4(31):eaat6114. doi: 10.1126/sciimmunol.aat6114

75. PrabhuDas M, Bonney E, Caron K, Dey S, Erlebacher A, Fazleabas A, et al. Immune mechanisms at the maternal-fetal interface: perspectives and challenges. Nat Immunol (2015) 16:328-34. doi: 10.1038/ni.3131

76. Mor G, Aldo P, Alvero AB. The unique immunological and microbial aspects of pregnancy. Nat Rev Immunol (2017) 17:469-82. doi: 10.1038/ nri.2017.64

77. Richani K, Soto E, Romero R, Espinoza J, Chaiworapongsa T, Nien JK, et al. Normal pregnancy is characterized by systemic activation of the complement system. J Matern Fetal Neonatal Med (2005) 17:239-45. doi: 10.1080/14767050500072722

78. Derzsy Z, Prohászka Z, Rigó J, Füst G, Molvarec A. Activation of the complement system in normal pregnancy and preeclampsia. Mol Immunol (2010) 47:1500-6. doi: 10.1016/j.molimm.2010.01.021

79. Sarma JV, Ward PA. The complement system. Cell Tissue Res (2011) 343:227-35. doi: 10.1007/s00441-010-1034-0

80. Nowicki S, Izban MG, Pawelczyk E, Agboto VK, Pratap S, Olson G, et al. Preterm labor: CD55 in maternal blood leukocytes. Am J Reprod Immunol (2009) 61:360-7. doi: 10.1111/j.1600-0897.2009.00702.x

81. Bischof P, Geinoz A, Herrmann WL, Sizonenko PC. Pregnancy-associated plasma protein A (PAPP-A) specifically inhibits the third component of human complement (C3). Placenta (1984) 5:1-7. doi: 10.1016/S0143-4004 (84) $80044-2$

82. Lin TM, Halbert SP, Spellacy WN. Measurement of pregnancy-associated plasma proteins during human gestation. J Clin Invest (1974) 54:576-82. doi: 10.1172/JCI107794

83. Jagadeesan V. Serum complement levels in normal pregnancy and pregnancy-induced hypertension. Int J Gynaecol Obstet (1988) 26:389-91. doi: 10.1016/0020-7292(88)90334-7

84. Baines MG, Millar KG, Mills P. Studies of complement levels in normal human pregnancy. Obstet Gynecol (1974) 43:806-10.

85. Belo L, Santos-Silva A, Rocha S, Caslake M, Cooney J, Pereira-Leite L, et al. Fluctuations in C-reactive protein concentration and neutrophil activation during normal human pregnancy. Eur J Obstet Gynecol Reprod Biol (2005) 123:46-51. doi: 10.1016/j.ejogrb.2005.02.022

86. Abbassi-Ghanavati M, Greer LG, Cunningham FG. Pregnancy and laboratory studies: a reference table for clinicians. Obstet Gynecol (2009) 114:1326-31. doi: 10.1097/AOG.0b013e3181c2bde8

87. Matsumoto K, Ogasawara T, Kato A, Homma T, Iida M, Akasawa A, et al. Eosinophil degranulation during pregnancy and after delivery by cesarean section. Int Arch Allergy Immunol (2003) 131(Suppl 1):34-9. doi: 10.1159/ 000070479

88. Luppi P, Haluszczak C, Betters D, Richard CA, Trucco M, DeLoia JA. Monocytes are progressively activated in the circulation of pregnant women. J Leukoc Biol (2002) 72:874-84. doi: 10.1034/j.1600-0897.2002.10041.x

89. Kindzelskii AL, Huang JB, Chaiworapongsa T, Fahmy RM, Kim YM, Romero R, et al. Pregnancy alters glucose-6-phosphate dehydrogenase trafficking, cell metabolism, and oxidant release of maternal neutrophils. J Clin Invest (2002) 110:1801-11. doi: 10.1172/JCI200215973

90. Kindzelskii AL, Ueki T, Michibata H, Chaiworapongsa T, Romero R, Petty HR. 6-phosphogluconate dehydrogenase and glucose-6-phosphate dehydrogenase form a supramolecular complex in human neutrophils that undergoes retrograde trafficking during pregnancy. J Immunol (2004) 172:6373-81. doi: 10.4049/jimmunol.172.10.6373

91. Crocker IP, Baker PN, Fletcher J. Neutrophil function in pregnancy and rheumatoid arthritis. Ann Rheum Dis (2000) 59:555-64. doi: 10.1136/ ard.59.7.555

92. Naccasha N, Gervasi MT, Chaiworapongsa T, Berman S, Yoon BH, Maymon E, et al. Phenotypic and metabolic characteristics of monocytes and granulocytes in normal pregnancy and maternal infection. Am J Obstet Gynecol (2001) 185:1118-23. doi: 10.1067/mob.2001.117682

93. Lampé R, Kövér Á, Szücs S, Pál L, Árnyas E, Ádány R, et al. Phagocytic index of neutrophil granulocytes and monocytes in healthy and preeclamptic pregnancy. J Reprod Immunol (2015) 107:26-30. doi: 10.1016/ j.jri.2014.11.001

94. Taniguchi K, Nagata H, Katsuki T, Nakashima C, Onodera R, Hiraoka A, et al. Significance of human neutrophil antigen-2a (NB1) expression and neutrophil number in pregnancy. Transfusion (2004) 44:581-5. doi: 10.1111/ j.1537-2995.2004.03298.x

95. Luppi P, Haluszczak C, Trucco M, Deloia JA. Normal pregnancy is associated with peripheral leukocyte activation. Am J Reprod Immunol (2002) 47:72-81. doi: 10.1034/j.1600-0897.2002.10041.x

96. Blazkova J, Gupta S, Liu Y, Gaudilliere B, Ganio EA, Bolen CR, et al. Multicenter Systems Analysis of Human Blood Reveals Immature Neutrophils in Males and During Pregnancy. J Immunol (2017) 198:247988. doi: 10.4049/jimmunol.1601855

97. Köstlin N, Kugel H, Spring B, Leiber A, Marmé A, Henes M, et al. Granulocytic myeloid derived suppressor cells expand in human pregnancy and modulate T-cell responses. Eur J Immunol (2014) 44:2582-91. doi: 10.1002/eji.201344200

98. Koldehoff M, Cierna B, Steckel NK, Beelen DW, Elmaagacli AH. Maternal molecular features and gene profiling of monocytes during first trimester pregnancy. J Reprod Immunol (2013) 99:62-8. doi: 10.1016/j.jri.2013.07.001

99. Veenstra van Nieuwenhoven AL, Bouman A, Moes H, Heineman MJ, de Leij LF, Santema J, et al. Endotoxin-induced cytokine production of monocytes of third-trimester pregnant women compared with women in the follicular phase of the menstrual cycle. Am J Obstet Gynecol (2003) 188:1073-7. doi: $10.1067 / \mathrm{mob} .2003 .263$

100. Melgert BN, Spaans F, Borghuis T, Klok PA, Groen B, Bolt A, et al. Pregnancy and preeclampsia affect monocyte subsets in humans and rats. PLoS One (2012) 7:e45229. doi: 10.1371/journal.pone.0045229

101. Groen B, van der Wijk AE, van den Berg PP, Lefrandt JD, van den Berg G, Sollie KM, et al. Immunological Adaptations to Pregnancy in Women with Type 1 Diabetes. Sci Rep (2015) 5:13618. doi: 10.1038/srep13618

102. Sacks GP, Redman CW, Sargent IL. Monocytes are primed to produce the Th1 type cytokine IL-12 in normal human pregnancy: an intracellular flow cytometric analysis of peripheral blood mononuclear cells. Clin Exp Immunol (2003) 131:490-7. doi: 10.1046/j.1365-2249.2003.02082.x

103. Germain SJ, Sacks GP, Sooranna SR, Soorana SR, Sargent IL, Redman CW. Systemic inflammatory priming in normal pregnancy and preeclampsia: the role of circulating syncytiotrophoblast microparticles. J Immunol (2007) 178:5949-56. doi: 10.4049/jimmunol.178.9.5949

104. Sacks GP, Studena K, Sargent K, Redman CW. Normal pregnancy and preeclampsia both produce inflammatory changes in peripheral blood leukocytes akin to those of sepsis. Am J Obstet Gynecol (1998) 179:80-6. doi: 10.1016/s0002-9378(98)70254-6

105. Al-ofi E, Coffelt SB, Anumba DO. Monocyte subpopulations from preeclamptic patients are abnormally skewed and exhibit exaggerated responses to Toll-like receptor ligands. PLoS One (2012) 7:e42217. doi: 10.1371/ journal.pone. 0042217

106. He YD, Xu BN, Song D, Wang YQ, Yu F, Chen Q, et al. Normal range of complement components during pregnancy: A prospective study. Am J Reprod Immunol (2020) 83:e13202. doi: 10.1111/aji.13202

107. Salmon JE, Heuser C, Triebwasser M, Liszewski MK, Kavanagh D, Roumenina $\mathrm{L}$, et al. Mutations in complement regulatory proteins 
predispose to preeclampsia: a genetic analysis of the PROMISSE cohort. PLoS Med (2011) 8:e1001013. doi: 10.1371/journal.pmed.1001013

108. Denny KJ, Woodruff TM, Taylor SM, Callaway LK. Complement in pregnancy: a delicate balance. Am J Reprod Immunol (2013) 69:3-11. doi: $10.1111 /$ aji. 12000

109. Heit JA, Kobbervig CE, James AH, Petterson TM, Bailey KR, Melton LJ. Trends in the incidence of venous thromboembolism during pregnancy or postpartum: a 30-year population-based study. Ann Intern Med (2005) 143:697-706. doi: 10.7326/0003-4819-143-10-200511150-00006

110. Mold C, Gewurz H, Du Clos TW. Regulation of complement activation by Creactive protein. Immunopharmacology (1999) 42:23-30. doi: 10.1016/ S0162-3109(99)00007-7

111. Berman S, Gewurz H, Mold C. Binding of C-reactive protein to nucleated cells leads to complement activation without cytolysis. J Immunol (1986) 136:1354-9.

112. Bíró A, Rovó Z, Papp D, Cervenak L, Varga L, Füst G, et al. Studies on the interactions between C-reactive protein and complement proteins. Immunology (2007) 121:40-50. doi: 10.1111/j.1365-2567.2007.02535.x

113. Amara U, Rittirsch D, Flierl M, Bruckner U, Klos A, Gebhard F, et al. Interaction between the coagulation and complement system. $A d v$ Exp Med Biol (2008) 632:71-9. doi: 10.1007/978-0-387-78952-1_6

114. Shanley DK, Kiely PA, Golla K, Allen S, Martin K, O'Riordan RT, et al. Pregnancy-specific glycoproteins bind integrin $\alpha \operatorname{IIb} \beta 3$ and inhibit the platelet-fibrinogen interaction. PLoS One (2013) 8:e57491. doi: 10.1371/ journal.pone.0057491

115. Kolaczkowska E, Kubes P. Neutrophil recruitment and function in health and inflammation. Nat Rev Immunol (2013) 13:159-75. doi: 10.1038/nri3399

116. Makinoda S, Mikuni M, Furuta I, Okuyama K, Sagawa T, Fujimoto S. Serum concentration of endogenous G-CSF in women during the menstrual cycle and pregnancy. Eur J Clin Invest (1995) 25:877-9. doi: 10.1111/j.13652362.1995.tb01699.x

117. Giaglis S, Stoikou M, Sur Chowdhury C, Schaefer G, Grimolizzi F, Rossi SW, et al. Multimodal Regulation of NET Formation in Pregnancy: Progesterone Antagonizes the Pro-NETotic Effect of Estrogen and G-CSF. Front Immunol (2016) 7:565. doi: 10.3389/fimmu.2016.00565

118. Kindzelskii AL, Clark AJ, Espinoza J, Maeda N, Aratani Y, Romero R, et al. Myeloperoxidase accumulates at the neutrophil surface and enhances cell metabolism and oxidant release during pregnancy. Eur J Immunol (2006) 36:1619-28. doi: 10.1002/eji.200535391

119. Vono M, Lin A, Norrby-Teglund A, Koup RA, Liang F, Loré K. Neutrophils acquire the capacity for antigen presentation to memory CD4. Blood (2017) 129:1991-2001. doi: 10.1182/blood-2016-10-744441

120. Nitsche JF, Jiang SW, Brost BC. Toll-like receptor-2 and toll-like receptor-4 expression on maternal neutrophils during pregnancy. Am J Reprod Immunol (2010) 64:427-34. doi: 10.1111/j.1600-0897.2010.00891.x

121. Veglia F, Perego M, Gabrilovich D. Myeloid-derived suppressor cells coming of age. Nat Immunol (2018) 19:108-19. doi: 10.1038/s41590-017-0022-x

122. Nair RR, Sinha P, Khanna A, Singh K. Reduced Myeloid-derived Suppressor Cells in the Blood and Endometrium is Associated with Early Miscarriage. Am J Reprod Immunol (2015) 73:479-86. doi: 10.1111/aji.12351

123. Mukherjee R, Kanti Barman P, Kumar Thatoi P, Tripathy R, Kumar Das B, Ravindran B. Non-Classical monocytes display inflammatory features: Validation in Sepsis and Systemic Lupus Erythematous. Sci Rep (2015) 5:13886. doi: 10.1038/srep13886

124. Tang MX, Hu XH, Liu ZZ, Kwak-Kim J, Liao AH. What are the roles of macrophages and monocytes in human pregnancy? J Reprod Immunol (2015) 112:73-80. doi: 10.1016/j.jri.2015.08.001

125. Faas MM, de Vos P. Maternal monocytes in pregnancy and preeclampsia in humans and in rats. J Reprod Immunol (2017) 119:91-7. doi: 10.1016/ j.jri.2016.06.009

126. Göhner C, Plösch T, Faas MM. Immune-modulatory effects of syncytiotrophoblast extracellular vesicles in pregnancy and preeclampsia. Placenta (2017) 60(Suppl 1):S41-51. doi: 10.1016/j.placenta.2017.06.004

127. Ziegler SM, Feldmann CN, Hagen SH, Richert L, Barkhausen T, Goletzke J, et al. Innate immune responses to toll-like receptor stimulation are altered during the course of pregnancy. J Reprod Immunol (2018) 128:30-7. doi: 10.1016/j.jri.2018.05.009
128. Hotchkiss RS, Monneret G, Payen D. Immunosuppression in sepsis: a novel understanding of the disorder and a new therapeutic approach. Lancet Infect Dis (2013) 13:260-8. doi: 10.1016/S1473-3099(13)70001-X

129. Döcke WD, Randow F, Syrbe U, Krausch D, Asadullah K, Reinke P, et al. Monocyte deactivation in septic patients: restoration by IFN-gamma treatment. Nat Med (1997) 3:678-81. doi: 10.1038/nm0697-678

130. Faas MM, Spaans F, De Vos P. Monocytes and macrophages in pregnancy and pre-eclampsia. Front Immunol (2014) 5:298. doi: 10.3389/fimmu.2014. 00298

131. Artis D, Spits H. The biology of innate lymphoid cells. Nature (2015) 517:293-301. doi: 10.1038/nature14189

132. Freud AG, Mundy-Bosse BL, Yu J, Caligiuri MA. The Broad Spectrum of Human Natural Killer Cell Diversity. Immunity (2017) 47:820-33. doi: 10.1016/j.immuni.2017.10.008

133. Brennan PJ, Brigl M, Brenner MB. Invariant natural killer T cells: an innate activation scheme linked to diverse effector functions. Nat Rev Immunol (2013) 13:101-17. doi: 10.1038/nri3369

134. Moffett A, Colucci F. Uterine NK cells: active regulators at the maternal-fetal interface. J Clin Invest (2014) 124:1872-9. doi: 10.1172/JCI68107

135. Burke SD, Seaward AV, Ramshaw H, Smith GN, Virani S, Croy BA, et al. Homing receptor expression is deviated on CD56+ blood lymphocytes during pregnancy in Type 1 diabetic women. PLoS One (2015) 10: e0119526. doi: 10.1371/journal.pone.0119526

136. Southcombe J, Redman C, Sargent I. Peripheral blood invariant natural killer $\mathrm{T}$ cells throughout pregnancy and in preeclamptic women. J Reprod Immunol (2010) 87:52-9. doi: 10.1016/j.jri.2010.07.003

137. Meggyes M, Miko E, Polgar B, Bogar B, Farkas B, Illes Z, et al. Peripheral blood TIM-3 positive NK and CD8+ T cells throughout pregnancy: TIM-3/ galectin-9 interaction and its possible role during pregnancy. PLoS One (2014) 9:e92371. doi: 10.1371/journal.pone.0092371

138. Zhang J, Shynlova O, Sabra S, Bang A, Briollais L, Lye SJ. Immunophenotyping and activation status of maternal peripheral blood leukocytes during pregnancy and labour, both term and preterm. J Cell Mol Med (2017) 21:2386-402. doi: 10.1111/jcmm.13160

139. Veenstra van Nieuwenhoven AL, Bouman A, Moes H, Heineman MJ, de Leij LF, Santema J, et al. Cytokine production in natural killer cells and lymphocytes in pregnant women compared with women in the follicular phase of the ovarian cycle. Fertil Steril (2002) 77:1032-7. doi: 10.1016/S00150282(02)02976-X

140. Borzychowski AM, Croy BA, Chan WL, Redman CWG, Sargent IL. Changes in systemic type 1 and type 2 immunity in normal pregnancy and preeclampsia may be mediated by natural killer cells. Eur J Immunol (2005) 35:3054-63. doi: 10.1002/eji.200425929

141. Sun J, Yang M, Ban Y, Gao W, Song B, Wang Y, et al. Tim-3 Is Upregulated in NK Cells during Early Pregnancy and Inhibits NK Cytotoxicity toward Trophoblast in Galectin-9 Dependent Pathway. PLoS One (2016) 11: e0147186. doi: 10.1371/journal.pone.0147186

142. Higuma-Myojo S, Sasaki Y, Miyazaki S, Sakai M, Siozaki A, Miwa N, et al. Cytokine profile of natural killer cells in early human pregnancy. Am J Reprod Immunol (2005) 54:21-9. doi: 10.1111/j.1600-0897.2005.00279.x

143. Zhao J, Lei Z, Liu Y, Li B, Zhang L, Fang H, et al. Human pregnancy upregulates Tim-3 in innate immune cells for systemic immunity. J Immunol (2009) 182:6618-24. doi: 10.4049/jimmunol.0803876

144. Das M, Zhu C, Kuchroo VK. Tim-3 and its role in regulating anti-tumor immunity. Immunol Rev (2017) 276:97-111. doi: 10.1111/imr.12520

145. Le Gars M, Seiler C, Kay AW, Bayless NL, Starosvetsky E, Moore L, et al. Pregnancy-Induced Alterations in NK Cell Phenotype and Function. Front Immunol (2019) 10:2469. doi: 10.3389/fimmu.2019.02469

146. Vacca P, Montaldo E, Croxatto D, Loiacono F, Canegallo F, Venturini PL, et al. Identification of diverse innate lymphoid cells in human decidua. Mucosal Immunol (2015) 8:254-64. doi: 10.1038/mi.2014.63

147. Glassman AB, Bennett CE, Christopher JB, Self S. Immunity during pregnancy: lymphocyte subpopulations and mitogen responsiveness. Ann Clin Lab Sci (1985) 15:357-62.

148. Coulam CB, Silverfield JC, Kazmar RE, Fathman CG. T-lymphocyte subsets during pregnancy and the menstrual cycle. Am J Reprod Immunol (1983) 4:88-90. doi: 10.1111/j.1600-0897.1983.tb00259.x 
149. Watanabe M, Iwatani Y, Kaneda T, Hidaka Y, Mitsuda N, Morimoto Y, et al. Changes in T, B, and NK lymphocyte subsets during and after normal pregnancy. Am J Reprod Immunol (1997) 37:368-77. doi: 10.1111/j.16000897.1997.tb00246.x

150. Kühnert M, Strohmeier R, Stegmüller M, Halberstadt E. Changes in lymphocyte subsets during normal pregnancy. Eur J Obstet Gynecol Reprod Biol (1998) 76:147-51. doi: 10.1016/S0301-2115(97)00180-2

151. Wegmann TG, Lin H, Guilbert L, Mosmann TR. Bidirectional cytokine interactions in the maternal-fetal relationship: is successful pregnancy a TH2 phenomenon? Immunol Today (1993) 14:353-6. doi: 10.1016/0167-5699(93) 90235-D

152. Wegmann TG. Foetal protection against abortion: is it immunosuppression or immunostimulation? Ann Immunol (Paris) (1984) 135D:309-12. doi: 10.1016/S0769-2625(84)81196-4

153. Szekeres-Bartho J, Wegmann TG. A progesterone-dependent immunomodulatory protein alters the Th1/Th2 balance. J Reprod Immunol (1996) 31:81-95. doi: 10.1016/0165-0378(96)00964-3

154. Piccinni MP, Beloni L, Livi C, Maggi E, Scarselli G, Romagnani S. Defective production of both leukemia inhibitory factor and type $2 \mathrm{~T}$-helper cytokines by decidual $\mathrm{T}$ cells in unexplained recurrent abortions. Nat Med (1998) 4:1020-4. doi: $10.1038 / 2006$

155. Saito S. Cytokine network at the feto-maternal interface. J Reprod Immunol (2000) 47:87-103. doi: 10.1016/S0165-0378(00)00060-7

156. Raghupathy R, Makhseed M, Azizieh F, Omu A, Gupta M, Farhat R. Cytokine production by maternal lymphocytes during normal human pregnancy and in unexplained recurrent spontaneous abortion. Hum Reprod (2000) 15:713-8. doi: 10.1093/humrep/15.3.713

157. Aghaeepour N, Ganio EA, Mcilwain D, Tsai AS, Tingle M, Van Gassen S, et al. An immune clock of human pregnancy. Sci Immunol (2017) 2. doi: 10.1126/sciimmunol.aan2946

158. Saito S, Sakai M, Sasaki Y, Tanebe K, Tsuda H, Michimata T. Quantitative analysis of peripheral blood Th0, Th1, Th2 and the Th1:Th2 cell ratio during normal human pregnancy and preeclampsia. Clin Exp Immunol (1999) 117:550-5. doi: 10.1046/j.1365-2249.1999.00997.x

159. Lissauer D, Goodyear O, Khanum R, Moss PA, Kilby MD. Profile of maternal CD4 T-cell effector function during normal pregnancy and in women with a history of recurrent miscarriage. Clin Sci (Lond) (2014) 126:347-54. doi: $10.1042 / \mathrm{CS} 20130247$

160. Matthiesen L, Ekerfelt C, Berg G, Ernerudh J. Increased numbers of circulating interferon-gamma- and interleukin-4-secreting cells during normal pregnancy. Am J Reprod Immunol (1998) 39:362-7. doi: 10.1111/ j.1600-0897.1998.tb00370.x

161. Nakashima A, Ito M, Yoneda S, Shiozaki A, Hidaka T, Saito S. Circulating and decidual Th17 cell levels in healthy pregnancy. Am J Reprod Immunol (2010) 63:104-9. doi: 10.1111/j.1600-0897.2009.00771.x

162. Fujisaki S, Mori N, Sasaki T, Maeyama M. Cell-mediated immunity in human pregnancy: Changes in lymphocyte reactivity during pregnancy and postpartum. Microbiol Immunol (1979) 23:899-907. doi: 10.1111/j.13480421.1979.tb02823.x

163. Marzi M, Vigano A, Trabattoni D, Villa ML, Salvaggio A, Clerici E, et al. Characterization of type 1 and type 2 cytokine production profile in physiologic and pathologic human pregnancy. Clin Exp Immunol (1996) 106:127-33. doi: 10.1046/j.1365-2249.1996.d01-809.x

164. Bailey K, Herrod HG, Younger R, Shaver D. Functional aspects of Tlymphocyte subsets in pregnancy. Obstet Gynecol (1985) 66:211-5.

165. Bhat NM, Mithal A, Bieber MM, Herzenberg LA, Teng NN. Human CD5+ B lymphocytes (B-1 cells) decrease in peripheral blood during pregnancy. J Reprod Immunol (1995) 28:53-60. doi: 10.1016/0165-0378 (94)00907-O

166. Christiansen JS, Andersen AR, Osther K, Peitersen B, Bach-Mortensen N, Lebech PE. The relationship between pregnancy, HCS and B lymphocytes. Acta Pathol Microbiol Scand C (1976) 84:313-8. doi: 10.1111/j.16990463.1976.tb00035.x

167. Moore MP, Carter NP, Redman CW. Lymphocyte subsets defined by monoclonal antibodies in human pregnancy. Am J Reprod Immunol (1983) 3:161-4. doi: 10.1111/j.1600-0897.1983.tb00239.x

168. Valdimarsson H, Mulholland C, Fridriksdottir V, Coleman DV. A longitudinal study of leucocyte blood counts and lymphocyte responses in pregnancy: a marked early increase of monocyte-lymphocyte ratio. Clin Exp Immunol (1983) 53:437-43.

169. Delgado I, Neubert R, Dudenhausen JW. Changes in white blood cells during parturition in mothers and newborn. Gynecol Obstet Invest (1994) 38:22735. doi: 10.1159/000292487

170. Iwatani Y, Amino N, Tachi J, Kimura M, Ura I, Mori M, et al. Changes of lymphocyte subsets in normal pregnant and postpartum women: postpartum increase in $\mathrm{NK} / \mathrm{K}$ (Leu 7) cells. Am J Reprod Immunol Microbiol (1988) 18:52-5. doi: 10.1111/j.1600-0897.1988.tb00235.x

171. Kraus TA, Engel SM, Sperling RS, Kellerman L, Lo Y, Wallenstein S, et al. Characterizing the pregnancy immune phenotype: results of the viral immunity and pregnancy (VIP) study. J Clin Immunol (2012) 32:300-11. doi: 10.1007/s10875-011-9627-2

172. Mahmoud F, Abul H, Omu A, Al-Rayes S, Haines D, Whaley K. Pregnancyassociated changes in peripheral blood lymphocyte subpopulations in normal Kuwaiti women. Gynecol Obstet Invest (2001) 52:232-6. doi: $10.1159 / 000052981$

173. Matthiesen L, Berg G, Ernerudh J, Håkansson L. Lymphocyte subsets and mitogen stimulation of blood lymphocytes in normal pregnancy. Am J Reprod Immunol (1996) 35:70-9. doi: 10.1111/j.1600-0897.1996.tb00010.x

174. Lima J, Martins C, Leandro MJ, Nunes G, Sousa MJ, Branco JC, et al. Characterization of $\mathrm{B}$ cells in healthy pregnant women from late pregnancy to post-partum: a prospective observational study. BMC Pregnancy Childbirth (2016) 16:139. doi: 10.1186/s12884-016-0927-7

175. Pazos M, Sperling RS, Moran TM, Kraus TA. The influence of pregnancy on systemic immunity. Immunol Res (2012) 54:254-61. doi: 10.1007/s12026012-8303-9

176. Dodson MG, Kerman RH, Lange CF, Stefani SS, O’Leary JA. T and B cells in pregnancy. Obstet Gynecol (1977) 49:299-302.

177. Birkeland SA, Kristoffersen K. T and B lymphocytes during normal human pregnancy: a longitudinal study. Scand J Immunol (1979) 10:415-9. doi: 10.1111/j.1365-3083.1979.tb01370.x

178. Ziegler KB, Muzzio DO, Matzner F, Bommer I, Ventimiglia MS, Malinowsky K, et al. Human pregnancy is accompanied by modifications in B cell development and immunoglobulin profile. J Reprod Immunol (2018) 129:40-7. doi: 10.1016/ j.jri.2018.07.003

179. Lima J, Cambridge G, Vilas-Boas A, Martins C, Borrego LM, Leandro M. Serum markers of B-cell activation in pregnancy during late gestation, delivery, and the postpartum period. Am J Reprod Immunol (2019) 81: e13090. doi: 10.1111/aji.13090

180. Birkeland SA, Kristoffersen K. Lymphocyte transformation with mitogens and antigens during normal human pregnancy: a longitudinal study. Scand $J$ Immunol (1980) 11:321-5. doi: 10.1111/j.1365-3083.1980.tb00240.x

181. Best JM, Banatvala JE, Watson D. Serum IgM and IgG responses in postnatally acquired rubella. Lancet (1969) 2:65-8. doi: 10.1016/S01406736(69)92386-1

182. Gusdon JP. Fetal and maternal immunoglobulin levels during pregnancy. Am J Obstet Gynecol (1969) 103:895-900. doi: 10.1016/S0002-9378(16) 34434-9

183. Mendenhall HW. Serum protein concentrations in pregnancy. I. Concentrations in maternal serum. Am J Obstet Gynecol (1970) 106:38899. doi: 10.1016/0002-9378(70)90364-9

184. Studd JW. Immunoglobulins in normal pregnancy, pre-eclampsia and pregnancy complicated by the nephrotic syndrome. J Obstet Gynaecol $\mathrm{Br}$ Commonw (1971) 78:786-90. doi: 10.1111/j.1471-0528.1971.tb00339.x

185. Benster B, Wood EJ. Immunoglobulin levels in normal pregnancy and pregnancy complicated by hypertension. J Obstet Gynaecol Br Commonw (1970) 77:518-22. doi: 10.1111/j.1471-0528.1970.tb03559.x

186. Song CS, Merkatz IR, Rifkind AB, Gillette PN, Kappas A. The influence of pregnancy and oral contraceptive steroids on the concentration of plasma proteins. Studies with a quantitative immunodiffusion method. Am J Obstet Gynecol (1970) 108:227-31. doi: 10.1016/0002-9378(70)90301-7

187. Amino N, Tanizawa O, Miyai K, Tanaka F, Hayashi C, Kawashima M, et al. Changes of serum immunoglobulins IgG, IgA, IgM, and IgE during pregnancy. Obstet Gynecol (1978) 52:415-20.

188. Marolis GB, Buckley RH, Younger JB. Serum immunogbulin cocentrations during normal pregnancy. Am J Obstet Gynecol (1971) 109:971-6. doi: $10.1016 / 0002-9378(71) 90275-4$ 
189. Larsson A, Palm M, Hansson LO, Basu S, Axelsson O. Reference values for alpha1-acid glycoprotein, alpha1-antitrypsin, albumin, haptoglobin, Creactive protein, IgA, IgG and IgM during pregnancy. Acta Obstet Gynecol Scand (2008) 87:1084-8. doi: 10.1080/00016340802428146

190. Bondt A, Rombouts Y, Selman MH, Hensbergen PJ, Reiding KR, Hazes JM, et al. Immunoglobulin G (IgG) Fab glycosylation analysis using a new mass spectrometric high-throughput profiling method reveals pregnancyassociated changes. Mol Cell Proteomics (2014) 13:3029-39. doi: 10.1074/ mcp.M114.039537

191. Bondt A, Selman MH, Deelder AM, Hazes JM, Willemsen SP, Wuhrer M, et al. Association between galactosylation of immunoglobulin $G$ and improvement of rheumatoid arthritis during pregnancy is independent of sialylation. J Proteome Res (2013) 12:4522-31. doi: 10.1021/pr400589m

192. Selman MH, Derks RJ, Bondt A, Palmblad M, Schoenmaker B, Koeleman $\mathrm{CA}$, et al. Fc specific IgG glycosylation profiling by robust nano-reverse phase HPLC-MS using a sheath-flow ESI sprayer interface. J Proteomics (2012) 75:1318-29. doi: 10.1016/j.jprot.2011.11.003

193. Zenclussen AC, Gentile T, Kortebani G, Mazzolli A, Margni R. Asymmetric antibodies and pregnancy. Am J Reprod Immunol (2001) 45:289-94. doi: 10.1111/j.8755-8920.2001.450504.x

194. Gutierrez G, Gentile T, Miranda S, Margni RA. Asymmetric antibodies: a protective arm in pregnancy. Chem Immunol Allergy (2005) 89:158-68. doi: $10.1159 / 000087964$

195. Panpatana P, Wasi C, Ruangpairoj T, Chunarmchai S, Theeravuthichai J, Thongcharoen P. Serum immunoglobulins in pregnancy and postpartum. J Med Assoc Thai (1974) 57:109-11.

196. Zoller AL, Schnell FJ, Kersh GJ. Murine pregnancy leads to reduced proliferation of maternal thymocytes and decreased thymic emigration. Immunology (2007) 121:207-15. doi: 10.1111/j.1365-2567.2006.02559.x

197. Clarke AG, Kendall MD. The thymus in pregnancy: the interplay of neural, endocrine and immune influences. Immunol Today (1994) 15:545-51. doi: 10.1016/0167-5699(94)90212-7

198. Mor G, Cardenas I. The immune system in pregnancy: a unique complexity. Am J Reprod Immunol (2010) 63:425-33. doi: 10.1111/j.16000897.2010.00836.x

199. de Man YA, Dolhain RJ, Hazes JM. Disease activity or remission of rheumatoid arthritis before, during and following pregnancy. Curr Opin Rheumatol (2014) 26:329-33. doi: 10.1097/BOR.0000000000000045

200. Pozzilli C, Pugliatti M, Group P. An overview of pregnancy-related issues in patients with multiple sclerosis. Eur J Neurol (2015) 22(Suppl 2):34-9. doi: 10.1111/ene.12797

201. Airas L. Hormonal and gender-related immune changes in multiple sclerosis. Acta Neurol Scand (2015) 132:62-70. doi: 10.1111/ane.12433

202. Jara LJ, Medina G, Cruz-Dominguez P, Navarro C, Vera-Lastra O, Saavedra MA. Risk factors of systemic lupus erythematosus flares during pregnancy. Immunol Res (2014) 60:184-92. doi: 10.1007/s12026-014-8577-1

203. Sykes L, MacIntyre DA, Yap XJ, Teoh TG, Bennett PR. The Th1:th2 dichotomy of pregnancy and preterm labour. Mediators Inflamm (2012) 2012:967629. doi: 10.1155/2012/967629

204. Keelan JA, Blumenstein M, Helliwell RJ, Sato TA, Marvin KW, Mitchell MD. Cytokines, prostaglandins and parturition-a review. Placenta (2003) 24 (Suppl A):S33-46. doi: 10.1053/plac.2002.0948

205. Cierny JT, Unal ER, Flood P, Rhee KY, Praktish A, Olson TH, et al. Maternal inflammatory markers and term labor performance. Am J Obstet Gynecol (2014) 210:447.el-6. doi: 10.1016/j.ajog.2013.11.038

206. Denney JM, Nelson EL, Wadhwa PD, Waters TP, Mathew L, Chung EK, et al. Longitudinal modulation of immune system cytokine profile during pregnancy. Cytokine (2011) 53:170-7. doi: 10.1016/j.cyto.2010.11.005

207. Piccinni MP, Giudizi MG, Biagiotti R, Beloni L, Giannarini L, Sampognaro S, et al. Progesterone favors the development of human T helper cells producing Th2-type cytokines and promotes both IL-4 production and membrane CD30 expression in established Th1 cell clones. J Immunol (1995) 155:128-33.

208. Piccinni MP, Scaletti C, Maggi E, Romagnani S. Role of hormone-controlled Th1- and Th2-type cytokines in successful pregnancy. J Neuroimmunol (2000) 109:30-3. doi: 10.1016/S0165-5728(00)00299-X

209. Norman JE, Yuan M, Anderson L, Howie F, Harold G, Young A, et al. Effect of prolonged in vivo administration of progesterone in pregnancy on myometrial gene expression, peripheral blood leukocyte activation, and circulating steroid hormone levels. Reprod Sci (2011) 18:435-46. doi: $10.1177 / 1933719110395404$

210. Zenclussen AC. Adaptive Immune Responses During Pregnancy. Am J Reprod Immunol (2013) 69:291-303. doi: 10.1111/aji.12097

211. Croy BA, Chantakru S, Esadeg S, Ashkar AA, Wei Q. Decidual natural killer cells: key regulators of placental development (a review). J Reprod Immunol (2002) 57:151-68. doi: 10.1016/S0165-0378(02)00005-0

212. Piguet PF, Vassalli P. Study of the thymic-derived or -independent nature of mouse spleen cells induced to proliferate in culture by various mitogens and antigens. Eur J Immunol (1973) 3:477-83. doi: 10.1002/eji.1830030805

213. Muzzio D, Zenclussen AC, Jensen F. The role of B cells in pregnancy: the good and the bad. Am J Reprod Immunol (2013) 69:408-12. doi: 10.1111/ aji.12079

214. Power DA, Catto GR, Mason RJ, MacLeod AM, Stewart GM, Stewart KN, et al. The fetus as an allograft: evidence for protective antibodies to HLAlinked paternal antigens. Lancet (1983) 2:701-4. doi: 10.1016/S0140-6736 (83)92246-8

215. Medina KL, Smithson G, Kincade PW. Suppression of B lymphopoiesis during normal pregnancy. J Exp Med (1993) 178:1507-15. doi: 10.1084/ jem.178.5.1507

216. Muzzio DO, Soldati R, Ehrhardt J, Utpatel K, Evert M, Zenclussen AC, et al. $B$ cell development undergoes profound modifications and adaptations during pregnancy in mice. Biol Reprod (2014) 91:115. doi: 10.1095/ biolreprod.114.122366

217. Hussein MR, Abd-Elwahed AR, Abodeif ES, Abdulwahed SR. Decidual immune cell infiltrate in hydatidiform mole. Cancer Invest (2009) 27:60-6. doi: 10.1080/07357900802161054

218. Grimaldi CM, Cleary J, Dagtas AS, Moussai D, Diamond B. Estrogen alters thresholds for B cell apoptosis and activation. J Clin Invest (2002) 109:162533. doi: $10.1172 / \mathrm{JCI} 0214873$

219. Prieto JMB, Felippe MJB. Development, phenotype, and function of nonconventional B cells. Comp Immunol Microbiol Infect Dis (2017) 54:38-44. doi: 10.1016/j.cimid.2017.08.002

220. Bansal AS, Haeney MR, Cochrane S, Pumphrey RS, Green LM, Bhavnani M, et al. Serum soluble CD23 in patients with hypogammaglobulinaemia. Clin Exp Immunol (1994) 97:239-41. doi: 10.1111/j.1365-2249.1994.tb06074.x

221. Yoshikawa T, Nanba T, Kato H, Hori K, Inamoto T, Kumagai S, et al. Soluble Fc epsilon RII/CD23 in patients with autoimmune diseases and Epstein-Barr virus-related disorders: analysis by ELISA for soluble Fc epsilon RII/CD23. Immunomethods (1994) 4:65-71. doi: 10.1006/immu.1994.1008

222. Goller ME, Kneitz C, Mehringer C, Müller K, Jelley-Gibbs DM, Gosselin EJ, et al. Regulation of CD23 isoforms on B-chronic lymphocytic leukemia. Leuk Res (2002) 26:795-802. doi: 10.1016/s0145-2126(02)00007-3

223. Cambridge G, Perry HC, Nogueira L, Serre G, Parsons HM, De La Torre I, et al. The effect of B-cell depletion therapy on serological evidence of B-cell and plasmablast activation in patients with rheumatoid arthritis over multiple cycles of rituximab treatment. J Autoimmun (2014) 50:67-76. doi: 10.1016/j.jaut.2013.12.002

224. Guo WJ, Qu X, Yang MX, Zhang WD, Liang L, Shao QQ, et al. Expression of BAFF in the trophoblast and decidua of normal early pregnant women and patients with recurrent spontaneous miscarriage. Chin Med J (Engl) (2008) 121:309-15.

225. Kreuzaler M, Rauch M, Salzer U, Birmelin J, Rizzi M, Grimbacher B, et al. Soluble BAFF levels inversely correlate with peripheral B cell numbers and the expression of BAFF receptors. J Immunol (2012) 188:497-503. doi: 10.4049/jimmunol.1102321

226. de Taeye SW, Rispens T, Vidarsson G. The Ligands for Human IgG and Their Effector Functions. Antibodies (Basel) (2019) 8. doi: 10.3390/ antib8020030

227. Jennewein MF, Goldfarb I, Dolatshahi S, Cosgrove C, Noelette FJ, Krykbaeva M, et al. Fc Glycan-Mediated Regulation of Placental Antibody Transfer. Cell (2019) 178:202-15.e14. doi: 10.1016/j.cell.2019.05.044

228. Abu-Raya B, Giles ML, Kollmann TR, Sadarangani M. The Effect of Timing of Tetanus-Diphtheria-Acellular Pertussis Vaccine Administration in Pregnancy on the Avidity of Pertussis Antibodies. Front Immunol (2019) 10:2423. doi: $10.3389 /$ fimmu.2019.02423

229. Arnold JN, Wormald MR, Sim RB, Rudd PM, Dwek RA. The impact of glycosylation on the biological function and structure of human 
immunoglobulins. Annu Rev Immunol (2007) 25:21-50. doi: 10.1146/ annurev.immunol.25.022106.141702

230. Nesspor TC, Raju TS, Chin CN, Vafa O, Brezski RJ. Avidity confers FçR binding and immune effector function to aglycosylated immunoglobulin G1. J Mol Recognit (2012) 25:147-54. doi: 10.1002/jmr.2155

231. Jung ST, Reddy ST, Kang TH, Borrok MJ, Sandlie I, Tucker PW, et al. Aglycosylated IgG variants expressed in bacteria that selectively bind FcgammaRI potentiate tumor cell killing by monocyte-dendritic cells. Proc Natl Acad Sci U S A (2010) 107:604-9. doi: 10.1073/ pnas. 0908590107

232. Ferrara $C$, Grau $S$, Jäger $C$, Sondermann $P$, Brünker $P$, Waldhauer I, et al. Unique carbohydrate-carbohydrate interactions are required for high affinity binding between FcgammaRIII and antibodies lacking core fucose. Proc Natl Acad Sci U S A (2011) 108:12669-74. doi: 10.2210/pdb3sgj/pdb

233. Shields RL, Lai J, Keck R, O'Connell LY, Hong K, Meng YG, et al. Lack of fucose on human IgG1 N-linked oligosaccharide improves binding to human Fcgamma RIII and antibody-dependent cellular toxicity. J Biol Chem (2002) 277:26733-40. doi: 10.1074/jbc.M202069200

234. Tandon R, Bhatia BD, Narang P. Neonatal infections: I-Maternal and cord serum IgG levels in relation to gestation and intrauterine growth. Indian J Pediatr (1984) 51:521-7. doi: 10.1007/BF02776614

235. Pitcher-Wilmott RW, Hindocha P, Wood CB. The placental transfer of IgG subclasses in human pregnancy. Clin Exp Immunol (1980) 41:303-8.

236. Sakaguchi S. Naturally arising Foxp3-expressing CD25+CD4+ regulatory $\mathrm{T}$ cells in immunological tolerance to self and non-self. Nat Immunol (2005) 6:345-52. doi: 10.1038/ni1178

237. Akbar AN, Vukmanovic-Stejic M, Taams LS, Macallan DC. The dynamic coevolution of memory and regulatory CD4+ T cells in the periphery. Nat Rev Immunol (2007) 7:231-7. doi: 10.1038/nri2037

238. Somerset DA, Zheng Y, Kilby MD, Sansom DM, Drayson MT. Normal human pregnancy is associated with an elevation in the immune suppressive CD25+ CD4+ regulatory T-cell subset. Immunology (2004) 112:38-43. doi: 10.1111/j.1365-2567.2004.01869.x

239. Fontenot JD, Gavin MA, Rudensky AY. Pillars Article: Foxp3 Programs the Development and Function of CD4+CD25+ Regulatory T Cells. Nat Immunol (2003) 4:330-6. J Immunol 2017; 198:986-92.

240. Chaouat G, Lédée-Bataille N, Zourbas S, Ostojic S, Dubanchet S, Martal J, et al. Cytokines, implantation and early abortion: re-examining the Th1/Th2 paradigm leads to question the single pathway, single therapy concept. Am J Reprod Immunol (2003) 50:177-86. doi: 10.1034/j.1600-0897.2003.00080.x

241. Jadidi-Niaragh F, Yousefi M, Memarian A, Hojjat-Farsangi M, Khoshnoodi J, Razavi SM, et al. Increased frequency of CD8+ and $\mathrm{CD} 4+$ regulatory $\mathrm{T}$ cells in chronic lymphocytic leukemia: association with disease progression. Cancer Invest (2013) 31:121-31. doi: 10.3109/ 07357907.2012.756110

242. Sakaguchi S, Sakaguchi N, Asano M, Itoh M, Toda M. Immunologic selftolerance maintained by activated T cells expressing IL-2 receptor alphachains (CD25). Breakdown of a single mechanism of self-tolerance causes various autoimmune diseases. J Immunol (1995) 155:1151-64.

243. Alijotas-Reig J, Llurba E, Gris JM. Potentiating maternal immune tolerance in pregnancy: a new challenging role for regulatory T cells. Placenta (2014) 35:241-8. doi: 10.1016/j.placenta.2014.02.004

244. Clark DA, Chaouat G. Regulatory T cells and reproduction: how do they do it? J Reprod Immunol (2012) 96:1-7. doi: 10.1016/j.jri.2012.07.007

245. Tilburgs T, Scherjon SA, van der Mast BJ, Haasnoot GW, Versteeg -D, Voort-Maarschalk M, et al. Fetal-maternal HLA-C mismatch is associated with decidual $\mathrm{T}$ cell activation and induction of functional $\mathrm{T}$ regulatory cells. J Reprod Immunol (2009) 82:148-57. doi: 10.1016/j.jri.2009.05.003

246. Zenclussen AC, Gerlof K, Zenclussen ML, Sollwedel A, Bertoja AZ, Ritter T, et al. Abnormal T-cell reactivity against paternal antigens in spontaneous abortion: adoptive transfer of pregnancy-induced $\mathrm{CD} 4+\mathrm{CD} 25+\mathrm{T}$ regulatory cells prevents fetal rejection in a murine abortion model. Am J Pathol (2005) 166:811-22. doi: 10.1016/S0002-9440(10)62302-4

247. Zhao JX, Zeng YY, Liu Y. Fetal alloantigen is responsible for the expansion of the $\mathrm{CD} 4(+) \mathrm{CD} 25(+)$ regulatory $\mathrm{T}$ cell pool during pregnancy. J Reprod Immunol (2007) 75:71-81. doi: 10.1016/j.jri.2007.06.052

248. Tilburgs T, Roelen DL, Van Der Mast BJ, De Groot-Swings GM, Kleijburg C, Scherjon SA, et al. Evidence for a selective migration of fetus-specific CD4
$+\mathrm{CD} 25$ bright regulatory $\mathrm{T}$ cells from the peripheral blood to the decidua in human pregnancy. J Immunol (2008) 180:5737-45. doi: 10.4049/ jimmunol.180.8.5737

249. Sasaki Y, Sakai M, Miyazaki S, Higuma S, Shiozaki A, Saito S. Decidual and peripheral blood CD4+CD25+ regulatory T cells in early pregnancy subjects and spontaneous abortion cases. Mol Hum Reprod (2004) 10:347-53. doi: 10.1093/molehr/gah044

250. Heikkinen J, Mottonen M, Alanen A, Lassila O. Phenotypic characterization of regulatory $\mathrm{T}$ cells in the human decidua. Clin Exp Immunol (2004) 136:373-8. doi: 10.1111/j.1365-2249.2004.02441.x

251. Tilburgs T, Roelen DL, van der Mast BJ, van Schip JJ, Kleijburg C, de Groot-Swings GM, et al. Differential distribution of CD4(+)CD25(bright) and CD8(+)CD28(-) T-cells in decidua and maternal blood during human pregnancy. Placenta (2006) 27(Suppl A):S47-53. doi: 10.1016/ j.placenta.2005.11.008

252. Steinborn A, Haensch GM, Mahnke K, Schmitt E, Toermer A, Meuer S, et al. Distinct subsets of regulatory $\mathrm{T}$ cells during pregnancy: is the imbalance of these subsets involved in the pathogenesis of preeclampsia? Clin Immunol (2008) 129:401-12. doi: 10.1016/j.clim.2008.07.032

253. Rolle L, Memarzadeh Tehran M, Morell-Garcia A, Raeva Y, Schumacher A, Hartig R, et al. Cutting Edge: IL-10-Producing Regulatory B Cells in Early Human Pregnancy. Am J Reprod Immunol (2013) 70:448-53. doi: 10.1111/ aji. 12157

254. Polanczyk MJ, Carson BD, Subramanian S, Afentoulis M, Vandenbark AA, Ziegler SF, et al. Cutting edge: estrogen drives expansion of the CD4+CD25+ regulatory T cell compartment. J Immunol (2004) 173:2227-30. doi: 10.4049/ jimmunol.173.4.2227

255. Jin LP, Chen QY, Zhang T, Guo PF, Li DJ. The CD4+CD25 bright regulatory $\mathrm{T}$ cells and CTLA-4 expression in peripheral and decidual lymphocytes are down-regulated in human miscarriage. Clin Immunol (2009) 133:402-10. doi: 10.1016/j.clim.2009.08.009

256. O'Garra A, Vieira P. Regulatory T cells and mechanisms of immune system control. Nat Med (2004) 10:801-5. doi: 10.1038/nm0804-801

257. Sakaguchi S, Sakaguchi N, Shimizu J, Yamazaki S, Sakihama T, Itoh M, et al. Immunologic tolerance maintained by $\mathrm{CD} 25+\mathrm{CD} 4+$ regulatory $\mathrm{T}$ cells: their common role in controlling autoimmunity, tumor immunity, and transplantation tolerance. Immunol Rev (2001) 182:18-32. doi: 10.1034/ j.1600-065X.2001.1820102.x

258. Santner-Nanan B, Peek MJ, Khanam R, Richarts L, Zhu E, Fazekas de St Groth B, et al. Systemic increase in the ratio between Foxp3+ and IL-17producing $\mathrm{CD} 4+\mathrm{T}$ cells in healthy pregnancy but not in preeclampsia. J Immunol (2009) 183:7023-30. doi: 10.4049/jimmunol.0901154

259. Sanz I. Rationale for B cell targeting in SLE. Semin Immunopathol (2014) 36:365-75. doi: 10.1007/s00281-014-0430-z

260. Blair PA, Noreña LY, Flores-Borja F, Rawlings DJ, Isenberg DA, Ehrenstein MR, et al. CD19(+)CD24(hi)CD38(hi) B cells exhibit regulatory capacity in healthy individuals but are functionally impaired in systemic Lupus Erythematosus patients. Immunity (2010) 32:129-40. doi: 10.1016/j.immuni.2009.11.009

261. Iwata Y, Matsushita T, Horikawa M, Dilillo DJ, Yanaba K, Venturi GM, et al. Characterization of a rare IL-10-competent B-cell subset in humans that parallels mouse regulatory B10 cells. Blood (2011) 117:530-41. doi: 10.1182/ blood-2010-07-294249

262. Rosser EC, Mauri C. Regulatory B cells: origin, phenotype, and function. Immunity (2015) 42:607-12. doi: 10.1016/j.immuni.2015.04.005

263. Bundhun PK, Soogund MZ, Huang F. Impact of systemic lupus erythematosus on maternal and fetal outcomes following pregnancy: A meta-analysis of studies published between years 2001-2016. J Autoimmun (2017) 79:17-27. doi: 10.1016/j.jaut.2017.02.009

264. Hong S, Banchereau R, Maslow BL, Guerra MM, Cardenas J, Baisch J, et al. Longitudinal profiling of human blood transcriptome in healthy and lupus pregnancy. J Exp Med (2019) 216:1154-69. doi: 10.1084/ jem.20190185

265. Qiu K, He Q, Chen X, Liu H, Deng S, Lu W. Pregnancy-Related Immune Changes and Demyelinating Diseases of the Central Nervous System. Front Neurol (2019) 10:1070. doi: 10.3389/fneur.2019.01070

266. Jethwa H, Lam S, Smith C, Giles I. Does Rheumatoid Arthritis Really Improve During Pregnancy? A Systematic Review and Metaanalysis. J Rheumatol (2019) 46:245-50. doi: 10.3899/jrheum.180226 
267. Hughes SE, Spelman T, Gray OM, Boz C, Trojano M, Lugaresi A, et al. Predictors and dynamics of postpartum relapses in women with multiple sclerosis. Mult Scler (2014) 20:739-46. doi: 10.1177/1352458513507816

268. Centers for Disease Control and Prevention. Pregnancy Mortality Surveillance System. Available at: https://www.cdc.gov/reproductivehealth/ maternal-mortality/pregnancy-mortality-surveillance-system.htm (Accessed on 12 May 2020).

269. Christophersen A, Lund EG, Snir O, Sola E, Kanduri C, Dahal-Koirala S, et al. Distinct phenotype of CD4(+) T cells driving celiac disease identified in multiple autoimmune conditions. Nat Med (2019) 25:734-7. doi: 10.1038/ s41591-019-0403-9

270. Apps R, Kotliarov Y, Cheung F, Han KL, Chen J, Biancotto A, et al. Multimodal immune phenotyping of maternal peripheral blood in normal human pregnancy. JCI Insight (2020) 5. doi: 10.1172/jci.insight.134838

271. Sbihi H, Jones MJ, MacIsaac JL, Brauer M, Allen RW, Sears MR, et al. Prenatal exposure to traffic-related air pollution, the gestational epigenetic clock, and risk of early-life allergic sensitization. J Allergy Clin Immunol (2019) 144:1729-31.e5. doi: 10.1016/j.jaci.2019.07.047
Conflict of Interest: BA is supported by the Canadian Health and Research Institute Vanier Canada Graduate scholarship. CM was supported by a Graduate Studentship from the BC Children's Hospital Research Institute. MS is supported via salary awards from the BC Children's Hospital Foundation, the Canadian Child Health Clinician Scientist Program and the Michael Smith Foundation for Health Research. MS has been an investigator on projects funded by GlaxoSmithKline, Merck, Pfizer, Sanofi-Pasteur, Seqirus, Symvivo and VBI Vaccines. All funds have been paid to his institute, and he has not received any personal payments. PL is supported by the BC Children's Hospital Investigator Grant Award Program.

Copyright (c) 2020 Abu-Raya, Michalski, Sadarangani and Lavoie. This is an open-access article distributed under the terms of the Creative Commons Attribution License (CC BY). The use, distribution or reproduction in other forums is permitted, provided the original author(s) and the copyright owner(s) are credited and that the original publication in this journal is cited, in accordance with accepted academic practice. No use, distribution or reproduction is permitted which does not comply with these terms. 